\title{
A review of germination and early growth as a proxy for plant fitness under petrogenic
}

\author{
contamination — knowledge gaps and recommendations
}

\author{
Navjot Kaur $^{\mathrm{a}^{*}}$, Todd E. Erickson ${ }^{\mathrm{a}, \mathrm{b}}$, Andrew S. Ball ${ }^{\mathrm{c}}$, Megan H. Ryan ${ }^{\mathrm{a}}$ \\ ${ }^{a}$ School of Plant Biology, The University of Western Australia, 35 Stirling Highway, \\ Crawley, WA 6009, Australia \\ ${ }^{b}$ Kings Park and Botanic Garden, Fraser Ave, Kings Park, WA 6005, Australia \\ ${ }^{c}$ School of Science, Centre for Environmental Sustainability and Remediation, RMIT \\ University, Plenty Road, Bundoora, Victoria 3083, Australia
}

*Corresponding Author: Tel: (+61 8) 64882206

E-mail: navjot.kaur@ research.uwa.edu.au

\begin{abstract}
Germination - an important stage in the life cycle of plants - is susceptible to the presence of soil contaminants. Since the early 1990s, the use of germination tests to screen multiple plant species to select candidates for phytoremediation has received much attention. This is due to its inexpensive methodology and fast assessment relative to greenhouse or field growth studies. Surprisingly, no comprehensive synthesis is available of these studies in the scientific literature. As more plant species are added to phytoremediation databases, it is important to encapsulate the knowledge thus far and revise protocols. In this review, we have summarised previously-documented effects of petroleum hydrocarbons on germination and seedling growth. The methods and materials of previous studies are presented in tabulated form. Common practice includes the use of cellulose acetate filter paper, plastic Petri dishes, and low numbers of seeds and replicates. A general bias was observed for the screening of cultivated crops as opposed to native species, even though the latter may be better suited to site conditions. The relevance of germination studies as important ecotoxicological tools is highlighted with the proposed use of root imaging software. Screening of novel plant species, particularly natives, is recommended with selection focussed on (i) species phylogeny, (ii) plant morphological and functional traits, and (iii) tolerance towards harsh environmental stresses. Recommendations for standardised protocols for germination and early growth monitoring are made in order to improve the robustness of statistical modelling and species selection in future phytoremediation evaluations and field programs.
\end{abstract}

KEYWORDS: Bioindicators, ecotoxicological assessment, PAHs, phytoremediation, seed germination, selection criteria

Capsule: Germination studies are important to rule out inefficient plant species from phytoremediation experiments and prove useful in assessing site ecotoxicological status. 


\section{CONTENTS}

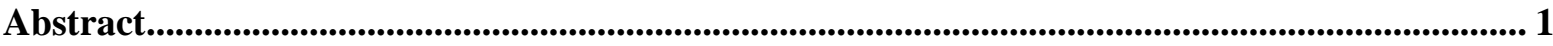

1. Introduction ....................................................................................................................................................... 3

2. Nature and fate of petrogenic contaminants in soil and their effect on germination............ 6

3. Methodological considerations with germination assays..................................................... 11

4. Changes in seed physiology and seedling morphology - processes at microscales.............. 12

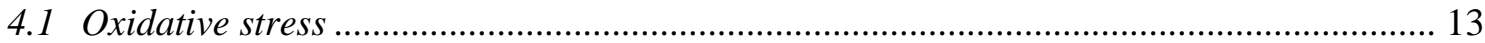

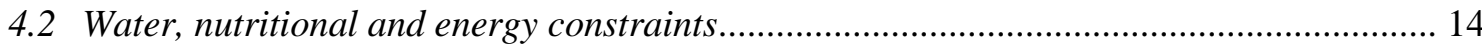

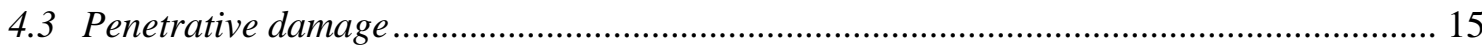

5. Germination as an ecotoxicological indicator ................................................................................ 16

6. Screening plant species for industrial and agricultural land use ............................................... 20

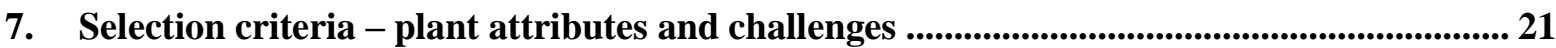

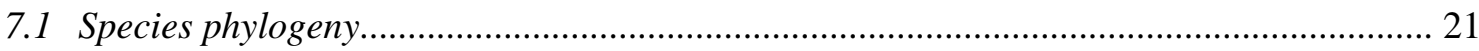

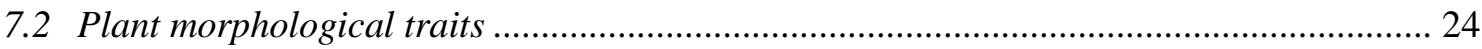

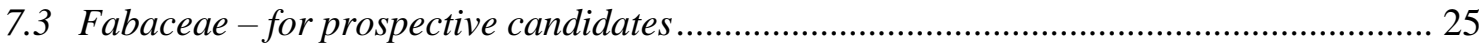

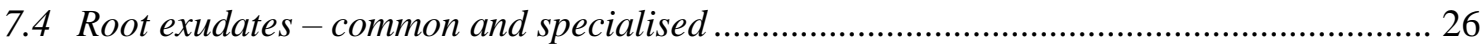

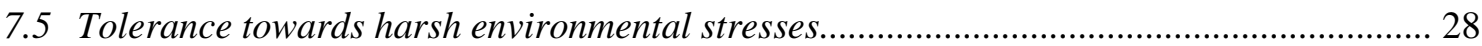

8. Recommendations - a prototype of improved germination protocols...................................... 29

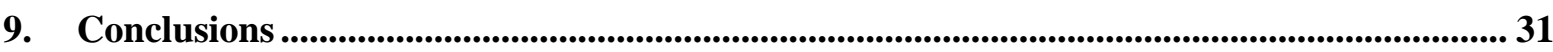

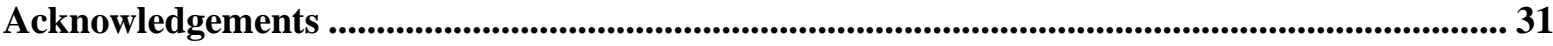

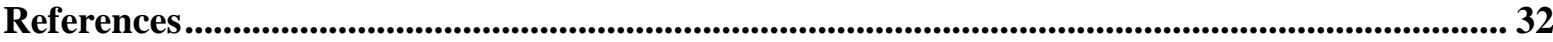




\section{Introduction}

Anthropogenic releases of petrochemicals contaminate terrestrial ecosystems with highmolecular-weight organic compounds of a carcinogenic and/or mutagenic nature (Banks and Schultz 2005; Corgié et al. 2004; Dong and Lee 2009; Maila and Cloete 2002). Spillage or loss of containment events commonly occur as a result of activities associated with the extraction, production and transportation of oil for both manufacturing industries and agricultural operations. Subsequent clean-up expenses for contaminated sites can run into billions of dollars. For example, in the USA, the largest producer of oil, it is estimated that the clean-up of all current hydrocarbon-contaminated sites will cost approximately US\$1 trillion (Kuiper et al. 2004; Stroud et al. 2007). In soils 'aged' with hydrocarbon contaminants, the residence time of recalcitrant fractions and their breakdown products can be more than decades. For example, Rezek et al. (2008) experimented with remediation of soil contaminated as long ago as World War II (1939-1945) and found that even after 50+ years, the concentrations of most polycyclic aromatic hydrocarbons (PAHs) were still high and they had not degraded significantly after 18 months of vegetation or fertilisation amendments. Such long-term persistence presents a high risk of contaminants leaching into groundwater and their potential bioaccumulation in the food chain; this is widely discussed in the literature (Collins et al. 2006; Fujikawa et al. 1993; Gao and Zhu 2004; McCready et al. 2000; Meador et al. 1995; Siddiqui and Adams 2002; Simonich and Hites 1995). As a result, the United States Environmental Protection Agency (USEPA) has registered 16 such PAHs as hazardous priority contaminants (Lamichhane et al. 2016).

As physical methods of remediation such as incineration and thermal desorption are unacceptable both on an environmental and economical basis (Henner et al. 1999; Joner and Leyval 2001; Smith et al. 2006), biologically-assisted remediation, i.e. remediation by soil microorganisms in the absence of plants, has been successfully employed. Traditionally, bioremediation techniques have been studied in conjunction with fertiliser supplements to ensure C:N:P ratios favour high microbial activity (Atlas 1991; Dibble and Bartha 1979; Walworth and Reynolds 1995). In general, a molar ratio of 100:10:1 is recommended and used in most studies (Leys et al. 2005). However, hydrocarbon spills also cause ecological disturbance of the soil indigenous micro-biota (Megharaj et al. 2000) and fertiliser additions rarely aid recuperation by the microbial biota to the pre-spill state, as it is mostly hydrocarbon degrader communities that persist. Indeed, evidence suggests that increased use of fertilisers can cause ammonia or nitrite toxicity to microorganisms (Tibbett et al. 2011). 
In the past two decades, phytoremediation (the use of plants to degrade contaminants of all types, e.g. organic, heavy metals) as a 'green liver' concept has been extensively investigated in relation to the degradation of hydrocarbon contaminants (Sandermann 1994). Phytoremediation garners high public acceptance due to its apparently sustainable and ecologically-holistic approach. Moreover, numerous studies have reported greater degradation of contaminants in the presence of plants than in microbe-only controls (Aprill and Sims 1990; Binet et al. 2000; Gaskin and Bentham 2010; Günther et al. 1996; Meng et al. 2011; Miya and Firestone 2001; Peng et al. 2009; Reilley et al. 1996). However, understanding the underlying mechanisms involved in the breakdown phases of a natural phyto-remediator system is slow owing to the complexity of the multiple mechanisms that plants can employ to remove the hydrocarbons (Table 1). It is also important to point out that some studies have reported that the growth of test plants in hydrocarbon-contaminated soil failed to catalyse efficient degradation compared with unplanted controls (e.g. Fang et al. 2001; Ferro et al. 1997; Olson et al. 2007b; Watkins et al. 1994). Plant species may differ in their tolerance of hydrocarbon contaminants; therefore, it is essential to screen more plant species for hydrocarbon tolerance to identify the most tolerant species and those best-suited to specific situations as there is huge variability in soil type, contaminant history, climatic conditions and nutritional status of contaminated sites. This may increase the likelihood of selecting species effective in causing biodegradation. 
Table 1 Mechanisms of phytoremediation

\begin{tabular}{ll}
\hline Types & Definition $^{1}$ \\
\hline In planta & $\begin{array}{l}\text { Ability of plants to uptake contaminants from the subsurface and } \\
\text { translocate to leaves or other parts (metals, inorganics compounds } \\
\text { only) } \\
\text { Diffusion of a volatile contaminant or its degradation product from } \\
\text { plant parts (volatile forms of organic and inorganic compounds) } \\
\text { Breakdown of contaminants inside the plant after uptake (organics of } \\
\text { appropriate hydrophobic range, inorganic compounds) }\end{array}$ \\
Phytodegradation & $\begin{array}{l}\text { Removal of the contaminant from the dissolved phase and thereafter } \\
\text { accumulation in the root system (inorganic compounds only) }\end{array}$
\end{tabular}

Ex planta

Phytostabilisation Reduced contaminant mobility due to plant-associated processes; physical (from wind and water erosion) and chemical (adsorption or precipitation of contaminant on plant roots or soil) (metals and inorganics only)

Phytohydraulics Use of phreatophytic trees and plants to transpire large volumes of water to limit leaching of the contaminant from the vadose zone after precipitation (wide range of contaminants)

\section{Interface}

Rhizodegradation Breakdown of contaminants within the plant root zone, i.e. the rhizosphere (mostly organic chemicals)

${ }^{1}$ As defined in USEPA 2000; Gerhardt et al. 2009; Germida et al. 2002; Kamath et al. 2004; Pilon-Smits 2005; Susarla et al. 2002; Wenzel 2009.

Screening of plant species for hydrocarbon tolerance, based on growth characteristics, requires months of plant development (Marques et al. 2010); maintenance of a large number of species in a replicated experiment over this time is expensive (Kirk et al. 2002). Associated procedures such as solvent extraction of contaminated soils and gas chromatography-mass spectrometry (GCMS) analyses of the extracts add further to the costs. To fast-track screening and reduce operational expenses, many authors have supported the use of germination screening tests (Maila and Cloete 2002; Smith et al. 2006). Also, the most effective approach to establishing vegetation on disturbed lands, such as contaminated sites, is direct seeding, as it ensures better survival and is cheaper than alternative transplanting techniques (Merritt and Dixon 2011; Palmerlee and Young 2010). Even so, high germination rates are desirable to reduce seed costs. To our knowledge, this review is the first attempt to consolidate the present knowledge on seed germination and early growth in hydrocarbon-contaminated soils. Phytoremediation databases such as PhytoPet (Frick et al. 1999), Clean-up Information (USEPA Clu-in), and the Kansas State and North Dakota University databases (KSU 2012; NDSU 2012) are being developed 
by enlisting species with high potential to enhance biodegradation. Most of these species grow naturally on contaminated sites and are, therefore, added to the list. Efficient use of these databases for future field trials will require extensive testing at germination and other plant growth stages. Therefore, it is important to address the knowledge gaps to improve the current germination protocols. In this review, we discuss the effect of contaminant characteristics on the physiological and morphological aspects associated with seed germination and the significance of germination tests as a tool for ecotoxicological assessment. For the purpose of formulating lists of prospective candidates to screen, selection criteria are compiled based on insights into beneficial plant attributes known to stimulate biodegradation. Lastly, we summarise the methodology of most of the previous germination trials, illustrate the key results with examples (from the literature and one of our studies) and propose recommendations for improved germination protocols.

\section{Nature and fate of petrogenic contaminants in soil and their effect on germination}

Petroleum (or crude oil) hydrocarbons (PHCs) can be broadly classified as (1) aliphatics (alkanes, alkenes, alkynes and cycloalkanes) and (2) aromatics (monoaromatics and polycyclic aromatic hydrocarbons, PAHs). The aliphatics contain chain(s) of carbon atoms, and the aromatics have one or more benzene rings (hexagonal arrangement of carbon atoms with alternate double bonds) bonded together. In the natural environment, although incomplete combustion of coal, wood and organic matter produces PAHs (Alkio et al. 2005; Samanta et al. 2002), the main source of contamination with these compounds is crude oil and its derivatives. Crude oil is a mixture of aliphatics, aromatics, resin and asphaltene (Colwell et al. 1977). It is separated into light, intermediate and heavy distillates by the process of fractional distillation (Table 2), where the mixture is heated and its fractions (vapours), based on their boiling points, condense back onto vertical trays placed along the length of the fractionation column. 
Table 2 Products of fractional distillation of crude oil and their constituents

\begin{tabular}{|c|c|c|c|}
\hline Distillate type & $\begin{array}{l}\text { No. of carbon } \\
\text { atoms }\end{array}$ & $\begin{array}{l}\text { Boiling point } \\
\text { range }\end{array}$ & Constituents (References) \\
\hline $\begin{array}{l}\text { Light (gasoline-range } \\
\text { organics, GROs) } \\
\text { e.g. solvents, petrol, } \\
\text { kerosene, jet fuel }\end{array}$ & $\mathrm{C}_{4}-\mathrm{C}_{12}$ & $<200^{\circ} \mathrm{C}$ & $\begin{array}{l}40-70 \% \text { alkanes and } \\
\text { cycloalkanes, }<10 \% \\
\text { alkenes, 20-50\% aromatics } \\
\text { (*BTEX and 2-ringed } \\
\text { PAHs) (USEPA 2000) }\end{array}$ \\
\hline $\begin{array}{l}\text { Intermediate (diesel- } \\
\text { range organics, } \\
\text { DROs) } \\
\text { e.g. diesel, heating oil }\end{array}$ & $\mathrm{C}_{8}-\mathrm{C}_{26}$ & $200-300^{\circ} \mathrm{C}$ & $\begin{array}{l}60-90 \% \text { alkanes and } \\
\text { cycloalkanes, }<5 \% \text { alkenes, } \\
10-30 \% \text { aromatics }(2-4- \\
\text { ringed PAHs) (Trapp et al. } \\
\text { 2001; USEPA 2000) }\end{array}$ \\
\hline $\begin{array}{l}\text { Heavy (mineral oil } \\
\text { range organics, } \\
\text { MOROs) } \\
\text { e.g. lubricating oil, } \\
\text { fuel oil, grease, } \\
\text { waxes }\end{array}$ & $\mathrm{C}_{15}-\mathrm{C}_{50}$ & $300-450^{\circ} \mathrm{C}$ & $\begin{array}{l}\text { Aromatics (4-6-ringed } \\
\text { PAHs), alkyl-PAHs } \\
\text { (ATSDR 1999) }\end{array}$ \\
\hline
\end{tabular}

In most experimental studies, soil is spiked with crude oil or diesel (fresh contamination) to evaluate the effect of an incremental increase in contaminant concentration on germination and emergence, and sometimes on the subsequent survival (Table 3). Other fuel types such as petrol, kerosene and transformer oil are much less studied (Sharonova and Breus 2012). The highest tested contamination levels were documented by Udo and Fayemi (1975) who observed a $100 \%$ and $50 \%$ reduction in germination at $10.6 \%$ and $4.2 \%$ crude oil, respectively, in freshlycontaminated soils. Usually, $>0.5 \%$ contamination is reportedly enough to produce a significant reduction in seed emergence (Gaskin et al. 2008). Here, it is important to mention that in some studies the terms 'germination' and 'emergence' have been used interchangeably. However, they represent distinct phases in life-stage transitions of a developing plant, so it is important not to compare germination results with those of emergence. Generally, germination is defined as the unequivocal appearance of the radicle (i.e. primary root) outside of the fruit/seed following incubation under suitable temperature, light and moisture conditions, whereas emergence is a post-germination early seedling stage understood as the protrusion of the shoot/plumule or cotyledons out of the growth medium in the field (Bewley et al. 2006). 
Most screening studies are specific-to-site(s) with one or similar source(s) of contamination. Therefore, it is uncommon in the literature to find comparisons among more than one contaminant type (Table 3). Reports on germination studies aimed at assessing individual constituents or pure compound(s) are limited and rather uninformative for applying to field situations across varying conditions and sites. However, these targeted assessments are useful to differentiate the effects of a single compound which are generally difficult to observe with the use of a composite mixture. On a broader scale, useful inferences can be drawn on the individual effects of volatile, aliphatic, aromatic and polar constituents by comparing different contaminants of inherently-dissimilar compositions (see studies cited in Table 3).

In one example of a comparative study, Henner et al. (1999) demonstrated a marked negative effect of volatile and hydrophilic aromatic compounds (identified as benzene, toluene, xylene isomers, styrene, indene and naphthalene) on the germination of several species by using Petri dish evaluations of various treatments that included: open versus closed lids, pure PAHs versus composite-contaminated soil, contaminated soil versus contaminated soil leachate, and freshly excavated versus aged vegetated soils. However, the germination assays versus field observations results were inconsistent. Previously, Chaineau et al. (1997) distilled fuel oil into light $\left(n \mathrm{C}_{9}-n \mathrm{C}_{14}\right)$ and heavy fractions $\left(>n \mathrm{C}_{15}\right)$ and found that the light fraction was 20 times more toxic than the heavy fraction. A recent study by MacKinnon and Duncan (2013) showed volatile branched cyclohexanes of diesel cause detrimental effects on germination and emergence. They hypothesised that the phytotoxicity of diesel in the early stages is short-lived as germination improves with time. Therefore, volatiles are likely to be largely responsible. Plice (1948) conjectured that the improvement in plant growth in successive seasons occurred due to the escape of volatile fractions.

In a pot experiment, Shahsavari et al. (2013) found no significant difference in the emergence of the 11 species that were tested in $1 \%$ diesel-engine or crude oil-contaminated soils $(10,000$ $\mathrm{mg} \mathrm{HC} \mathrm{kg}{ }^{-1}$ ). Contrary to these results, we undertook a study assessing the emergence potential of a selection of Australian native species compared against a suite of exotics (Fig. 1), where emergence in crude oil was far greater than in diesel-contaminated soils. Viability and optimal germination temperature were first assessed to determine the most suitable test conditions. After this, seeds of all species were assessed in a 1.5\%, 3\% and 6\% contamination with crude oil or diesel in aluminium foil dishes $(15 \times 9 \times 7 \mathrm{~cm})$ containing $600 \mathrm{~g}$ of contaminated or control white sand. We found that $1.5 \%$ diesel was as lethal as $3 \%$ crude oil in some cases. Diesel oil is a complex mixture of aliphatic (80-90\%) and aromatic (20-10\%) hydrocarbons 
(Ogbo et al. 2009; Serrano et al. 2009). As mentioned earlier, the higher concentration of volatile and aliphatic compounds in diesel was likely responsible for its greater toxicity (Henner et al. 1999) and probably caused variation in the germination response of nearby replicates.

In some instances, aged or low levels of fresh contamination in soils results in more germination (Reed and Glick 2005). This phenomenon is known as hormesis (Calabrese 2005; Kirk et al. 2002; Ma et al. 2010) and has been observed in most studies for at least one tested species (e.g. Kirk et al. 2002; Salanitro et al. 1997; Shahsavari et al. 2013; Rodanthe chlorocephala in Fig. 1). Hormesis results from the plant response to a slight level of stress optimising its physiological processes to give a head start to the developing embryo and often results in higher germination counts. Hormesis extends beyond seed germination, by enhancing crop growth (Carr 1919; Harper 1939) and early flowering (Vwioko and Fashemi 2005) in oilcontaminated soils. Reed and Glick (2005) suggested that at low concentrations, hydrocarbons may play a similar role as phytohormones, such as auxins. However, other processes may also be important including (i) oil contamination killing microbes thereby enhancing the amounts of soil nutrients, ii) the presence of compounds in oil that promote plant growth, and (iii) biological nitrogen fixation which may increase with the presence of oil in the soil (Baker 1971). Recently, some studies have documented the hormesis effect of benzo( $\alpha$ )-pyrene (a common PAH) on germination (Chigbo and Batty 2013; Diao et al. 2011), while others have found no adverse impact on seedling emergence (Ren et al. 1996; Sverdrup et al. 2007). 


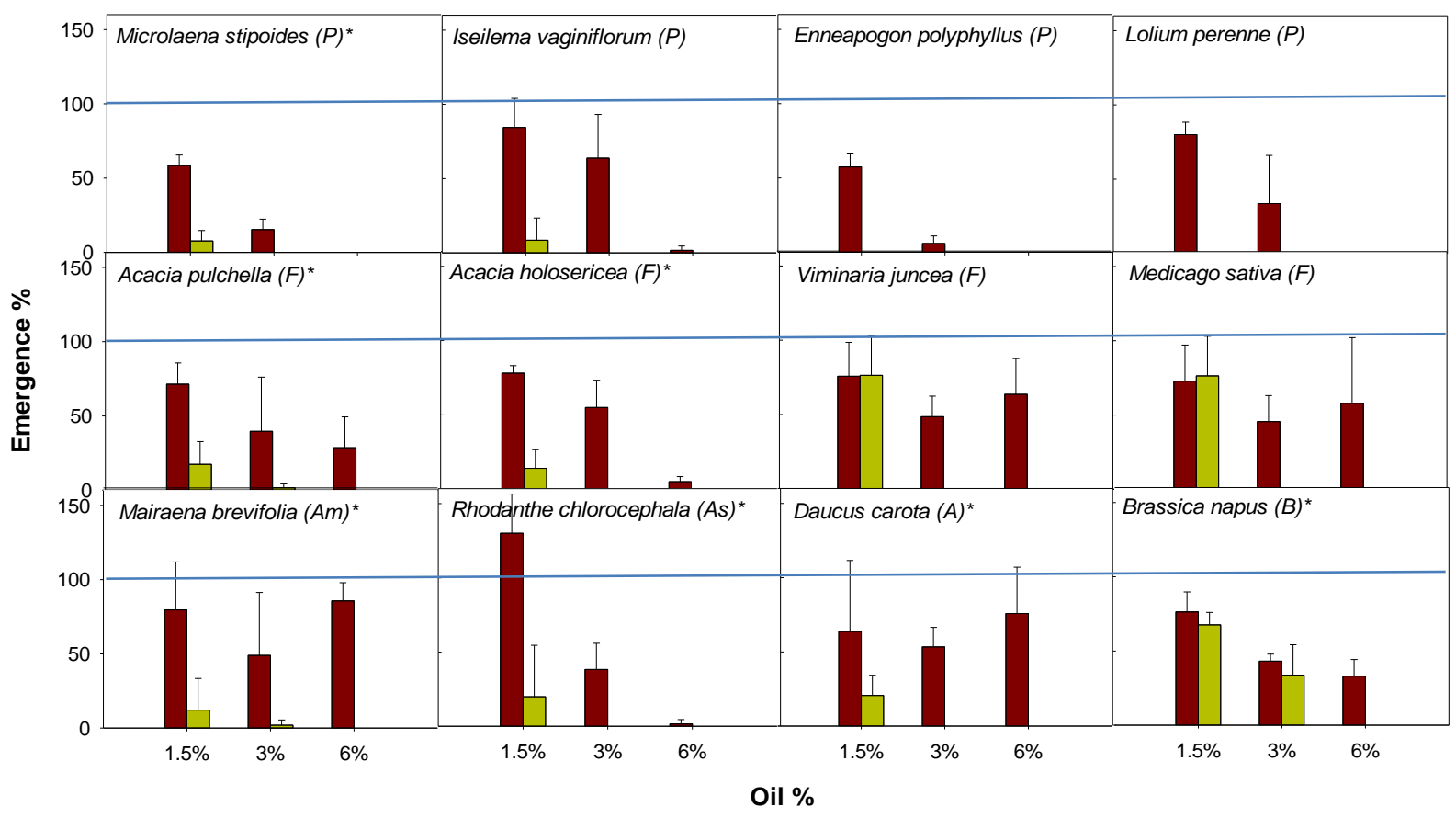

Fig. 1 Emergence of seeds (normalised to uncontaminated control as $100 \%$, blue line) in white sand spiked with crude oil ( ) or diesel ( $)$; and grown at optimum temperatures; $20 / 10^{\circ} \mathrm{C}\left({ }^{*}\right)$ or $35 / 20^{\circ} \mathrm{C}$. In parentheses, family names: P-Poaceae; F-Fabaceae, Am-Amaranthaceae, As-Asteraceae, A-Apiaceae and B-Brassicaceae. One exotic species is placed in each row (right side).(Means $\pm \mathrm{SE}, \mathrm{n}=3$, each replicate contains $>50$ seeds with viability $>70 \%)$.

In comparison to freshly-contaminated soils, most seeds germinate better in soils rested with contamination ('aged') before the addition of seeds. Adam and Duncan (2002) proposed that the loss of volatiles alone is not always responsible for this improvement and that reduced bioavailability also plays a significant role. As the spill of hydrocarbons in the soil matures with time, some compounds adsorb to organic matter and colloids in the soil; hence, only a small portion of the total remains bioavailable (Tao et al. 2009). Bioavailability can be defined as the fraction of contaminant present that can be readily assimilated or transformed by living organisms, commonly microorganisms (Cofield et al. 2008). While whole product toxicity is of prime interest, the byproducts formed by the natural weathering of the parent compounds can induce plant stress. For instance, Ren et al. (1996) studied the effects of photo-induced PAHs (anthracene, benzo( $\alpha$ )pyrene and fluoranthene) on the germination and early seedling development of Brassica napus. They found that, on exposure to sunlight, PAHs produce compounds that are more toxic and water soluble than parent compounds, with root fresh 
weight (but not germination percentage, frequency, root numbers or root size) negatively affected by the photo-modified compounds, which suggests poor root-water retention. This result may explain why many species which germinate well in oil-contaminated environments do not subsequently survive well (Besalatpour et al. 2008; Chaineau et al. 1997; Henner et al. 1999).

In practical scenarios, before final abandonment, sites may be contaminated sporadically for long periods due to their proximity to a contamination source such as machinery. Therefore, a challenge in the reclamation of such sites is the mixed effects of fresh and aged contamination caused by contaminants of varying composition and the overall heterogeneity caused by landscape features such as soil type (discussed in section 7.5).

\section{Methodological considerations with germination assays}

There is a lack of consensus among the results of germination studies, even when similar plant species are used. Other than the presence of organic matter and hydrocarbon weathering, these differences are mostly attributed to the use of different germination methodologies (ReynosoCuevas et al. 2008). To evaluate the germination potential of seeds in oil, germination assays have used a range of growing mediums and containers. The use of aged or freshly-contaminated field soil is most common (Table 3), although some authors have also used sterile sand (Chaineau et al.1997) and in vitro gels (Reynoso-Cuevas et al. 2008). In many cases, filter paper has also been used as a test medium (e.g. MacKinnon and Duncan 2013; Graj et al. 2013). However, cellulose, the main component of filter papers, sorbs hydrophobic organic compounds (Lamichhane et al. 2016) and may reduce their bioavailability in a preferential manner. Earlier, Wang (1993) criticised the use of filter papers for reducing the toxicities of metal cations, silver and cadmium. However, phenol, also a test substrate, showed no difference in germination among various materials that used filter paper, growth pouches and Petri dish seed trays. Petri dishes, unlike pots, are convenient to use for germination tests because they offer several benefits such as less shelf space and material (contaminant, fertiliser, etc.), the ability to test multiple plant species simultaneously, and transparency for light penetration. Petri dishes are made of polystyrene, a polymer inert to weak acids and bases. However, recently, Rochman et al. (2013) conducted three-monthly samplings for one year of two areas in San Diego Bay and tested 25 PAHs. They found that the pellets of polystyrene sorbed 8-200 times higher concentrations from time zero, when compared with other common polymers, namely polyethylene terephthalate (PET), high-density polyethylene (HDPE), 
polyvinyl chloride (PVC), low-density polyethylene (LDPE) and polypropylene (PP). Differences in results are also reported depending on whether Petri dishes remained open or closed during germination assays, presumably because most oil types have a significant amount of volatile compounds. Henner et al. (1999) reported a 50\% decline in seed germination in closed Petri dishes due to volatiles in tar at $150 \mathrm{mg} \mathrm{kg}^{-1}(0.015 \%)$. Because these conditions are not experienced by germinating seeds in field or glasshouse environments, we suggest that closed Petri dishes should not be used where high concentrations of volatiles are present. Also, those made from polystyrene should be used cautiously, more for the purpose of pure compound studies than composite.

\section{Changes in seed physiology and seedling morphology - processes at microscales}

Often the main goal of a germination assay is to select one or a few species, from many possible options, for use in the bioremediation of a specific site and contaminant type (Marques et al. 2010). Species are ranked based only on germination counts or rates and, sometimes, aspects of early seedling performance such as above- or below-ground dry weight or length. This focus on plant selection is one reason why the mechanisms for differential sensitivity of plant species to organic contaminants remain poorly researched. There are many common symptoms observed during seed germination and seedling growth in oil-contaminated soils, which are summarised in Figure 2. We now discuss three widely-used explanations for these symptomsoxidative stress, water and nutrient constraints, and penetrative damage. 


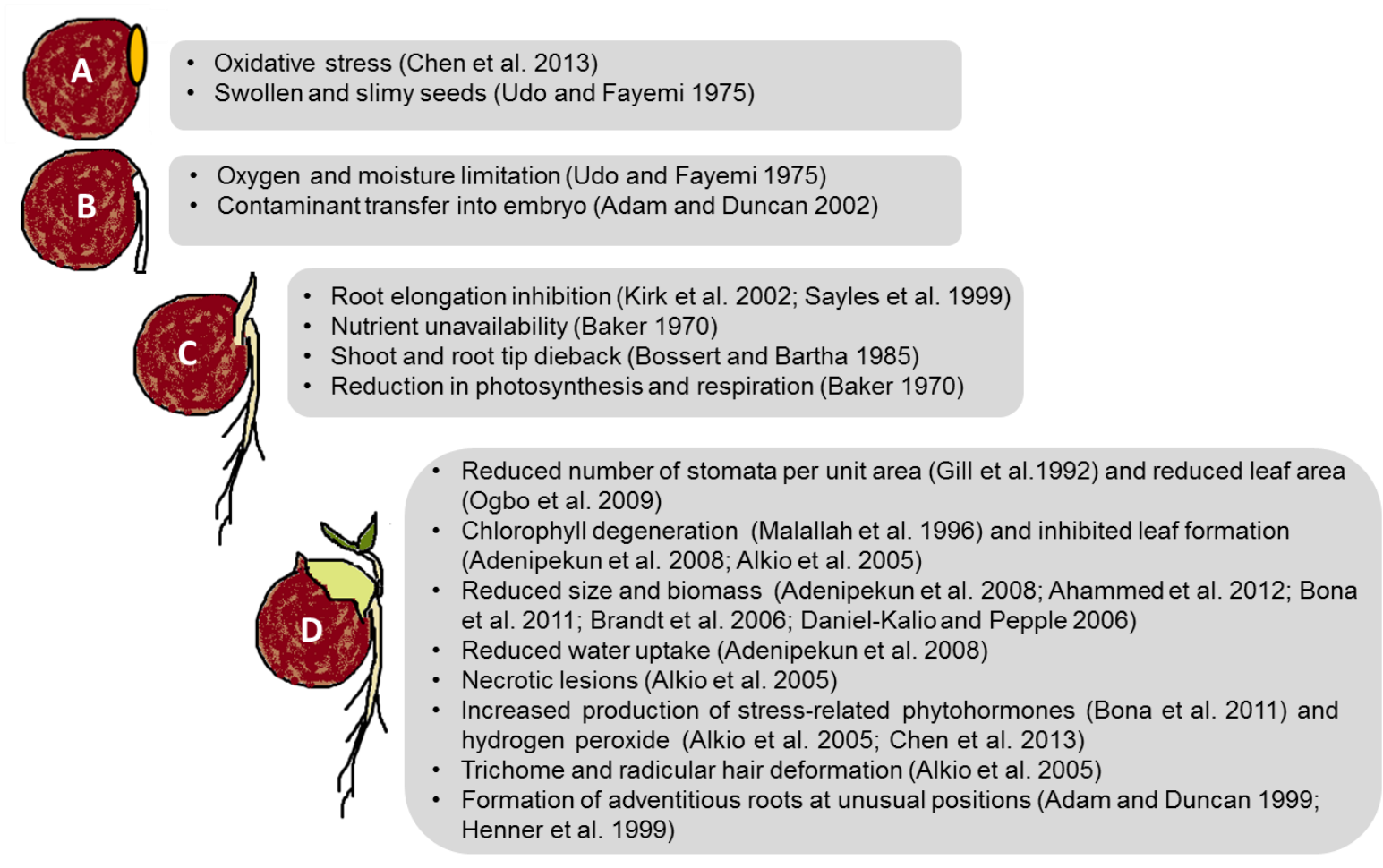

Fig. 2 Common symptoms and limitations for seeds germinating in hydrocarbon-contaminated soil during successive developmental stages (A - Imbibition, B - Germination, C - Emergence and D - Seedling).

\subsection{Oxidative stress}

Insufficient aeration in soil occurs when the air-filled pore space decreases due to the spillage of hydrocarbons (De Jong 1980; Gudin and Syratt 1975; Rowell 1977). This can lead to oxidative stress, which is defined as the disturbance of the cellular redox state under various environmental stresses including the lack of oxygen (Mittler et al. 2004). Generally, in response to oxidative stress, plants produce high concentrations of reactive oxygen species (ROS) in their tissues. ROS are chemically-reactive compounds containing oxygen such as superoxide, peroxide, hydroxyl radical and singlet oxygen, and high concentrations of these cause cell damage (Liu et al. 2009). Several PAHs and their metabolites such as phenanthrene, fluoranthene, 3,4-benzopyrene and 1,2-benzacenaphthene can bioaccumulate in plant tissue and are believed to produce ROS (Kolb and Harms 2000; Liu et al. 2009). Analyses of hydrogen peroxide concentration, cellular DNA damage and enzyme activities have been used to study the cell's response to oxidative stress in response to high salt, drought and heavy metals. Under stressed conditions, hydrogen peroxide, stored in peroxisomes as a normal byproduct of metabolic pathways, diffuses out due to a loss of membrane integrity and damage 
to cell metabolism (Chen et al. 2013, references therein). Histological studies using diaminobenzidine staining of Acorus tatarinowii leaf samples showed an increase in hydrogen peroxide accumulation with increased diesel stress (Chen et al. 2013). Alkio et al. (2005) also found that phenanthrene-induced production of hydrogen peroxide was linked to the processes involved in cell death in shoots of Arabidopsis thaliana. Various authors have agreed that the formation of a persistent hydrophobic organic film on the surface of seeds growing in contaminated soil impedes gaseous exchange in the embryo, eventually killing it (Adam and Duncan 2002; Baker 1970; Chaineau et al. 1997). Increased microbial activity in the presence of oil as an additional carbon source is another possible cause of oxygen depletion around an oil-treated seed (Amakiri and Onofeghara 1984; Gudin and Syratt 1975; Udo and Fayemi 1975).

\subsection{Water, nutritional and energy constraints}

Contamination with hydrocarbons also affects the ability of soil to provide moisture and nutrients to plants (Reilley et al. 1996). The availability of both is critical during germination and seedling development. Due to the hydrophobic nature of oil, water spreads unevenly in oilcontaminated soils, leading to water deficiency in some areas (Merckl et al. 2005). Moreover, the presence of hydrocarbons may impede the ability of roots to explore soil for water. Once a seed has germinated under normal conditions, early root development occurs primarily due to cell expansion as opposed to cell division (Taiz et al. 2015). Ren et al. (1996) found that PAH toxicity led to the production of shorter roots in seedlings and inhibited root fresh weight accumulation. They suggested that PAHs can cause mechanical disruption to the fragile cellular membranes of new roots and thereby diminish their capacity to retain water. Cell expansion processes may also be impeded in contaminated soils due to disruption of hormone action (auxins) or cell organelle metabolism (Maila and Cloete 2002). A close look at root tips of four-day-old Vigna unguiculata seedlings germinated in crude oil-contaminated soil revealed a significant reduction in cell size and mitotic activity (Achuba 2006). Bona et al. (2011) also found that the expansion of cotyledons following emergence was slower in diesel-contaminated soil.

Closely related to water deficit are the nutritional constraints experienced by young seedlings in contaminated environments. The presence of oil in the soil can cause a significant reduction in plant-available forms of phosphorus, potassium (Dimitrow and Markow, 2000) and nitrate 
(Baldwin 1922; Murphy 1929), and an increase in the concentrations of elements, such as manganese and sulfur, which can be toxic to plants (McGill and Rowell 1977).

In addition to reducing water and nutrient availability, oil contamination may affect plant growth through negative impacts on plant carbon exchange. Early experiments that investigated the herbicidal effects of oils on plant leaf surfaces found decreased respiration and photosynthesis in oil-contaminated plants (Baker 1970 and references therein). In addition, Achuba (2006) recorded reduced activity for two starch-degrading enzymes, total amylase and starch phosphorylase, in the cotyledons of seeds germinated in the presence of crude oil, which suggests inaccessibility of native reserves for energy production. However, compared to mangroves and algae (Naidoo et al. 2010), there are no reports on the effects of oilcontaminated soils on respiration and photosynthesis in terrestrial plants.

\subsection{Penetrative damage}

Depending on the soil characteristics, the aforementioned negative effect of oil contamination on seed germination and seedling emergence caused from reduced levels of oxygen, moisture and nutrients could be overcome by selecting plant species adapted to germinate in similar conditions. However, the most potent damage to seeds is that of a penetrative nature, i.e. movement of a pollutant into the seed embryo. As the wetting capacity (hydrophilicity) and penetrating power of a dry seed are high, the embryo can die if in contact with oil due to the penetration of oil components through the seed coat. Oil can enter seeds via the micropylar end (dicots), the coleorhizal end (monocots) or even through injured tissue, with the rate of penetration affected by the integrity and hardness of the seed coat (Amakiri and Onofeghara 1984). Adam and Duncan (2002) used relatively easily-penetrable Linum usitatissimum seeds that were pre-soaked in diesel for a week; after two weeks, $70 \%$ had germinated compared with 97\% in the controls. In contrast, after eight months soaking in crude oil, seeds of Capsicum frutescens remained $100 \%$ viable, but the germination lag phase increased three-fold compared to the controls (Amakiri and Onofeghara 1984). The difference between species may be due selective permeability of the seed coats (Wierzbicka and Obidzińska 1998) which plays an important role in protecting the embryo from external hazards. Klokk (1984) argued that seed resistance to phytotoxic properties of oils should be attributed to cell wall structure. Seed size may play an important role since large seeds generally have thicker seed coats than small seeds (Fenner 1985). Robson et al. (2004a) investigated the abundance of eight species on a contaminated site and categorised them into four groups based on seed mass. Contaminated 
plots had significantly more seeds in the second highest seed mass group (0.1-9.9 mg) than the uncontaminated plots. The authors speculated that due to low fertility at the contaminated site (C:N ratio 27:1), the large seeds were able to draw upon their reserves. There is no information available on the effect of seed constituents such as soluble carbohydrates, lipids or proteins on hydrocarbon penetration or resistance. Several studies have pointed out that the intensity of translocation of hydrophilic organics into the plant biomass is closely correlated with the octanol-water coefficient, $\mathrm{K}_{\mathrm{ow}}$ (Schneunert et al. 1994; Simonich and Hites 1995; Trapp et al. 1990). We assume that the penetration of hydrophilic organics such as naphthalenes into the seed is correlated with $\mathrm{K}_{\mathrm{ow}}$, as is the case with the rest of the plant.

\section{Germination as an ecotoxicological indicator}

Although some reports have mentioned the lack of sensitivity of germination tests in predicting the subsequent growth of a species in contaminated environments, many researchers consider that these assays are a promising tool for assessing the ecotoxicity of contaminated soils (Banks and Schultz 2005; Kirk et al. 2002; Maila and Cloete 2005; Wang et al. 2001). The plant species recommended by various agencies for this purpose are listed in Table 4. Germination bioassays have been adopted to evaluate the phytotoxic effects of heavy metals (Chang et al. 1992), herbicides (Boutin et al. 2004) and explosives (Frische 2003; Gunderson et al. 1997). The use of a germination ecotoxicological assessment for petrogenic contaminants is fairly new. Soil phytoxicity consistently affects germination dynamics (Sharonova and Breus 2012) and could, therefore, be used to build a predictive germination tool for future ecotoxicological assessments. A common method for estimating ecotoxicity is based on measuring the total concentration of contaminants after extraction with organic solvents. It tends to overestimate contaminant bioavailability (Cofield et al. 2008; Tang et al. 2002) and so is of little use for predicting ecotoxicity (Banks and Schultz 2005; Baud-Grasset et al. 1993). In this regard, owing to their simple but repeatable methodology, low cost, moderate sensitivity to contaminants and potential for use in situ and ex situ, germination assays may be useful bioindicators for estimating ecotoxicity (Maila and Cleote 2005; Siciliano et al. 1997). Additionally, the seeds required for such assays can be purchased in bulk, have low maintenance costs, lose viability slowly when stored correctly and, therefore, can be used for repeated testing, as may be required to track the impact of remediation over time (Wang et al. 2001). Suggested species for this purpose based on their stability and high reproducibility are Lepidium sativum (Maila and Cleote 2002), Cucumis sativus (Wang et al. 2001), Vicia faba (Malallah et al. 1996) and Lactuca sativa (Banks and Schultz 2005). 
Table 4 Plant species recommended by environmental regulatory agencies for use in ecotoxicity assessments of land contaminated with organic contaminants (adapted from Wang and Freemark 1995).

\begin{tabular}{ll}
\hline $\begin{array}{l}\text { Agency/report } \\
\text { year }\end{array}$ & Species required \\
\hline FDA 1987 & Phaseolus vulgaris, Brassica oleracea, Daucus carota, Zea mays, \\
& Cucumis sativus, Lactuca sativa, Avena sativa, Lolium perenne, Glycine \\
& max, Solanum lycopersicum, Triticum aestivum \\
OECD 1984 & Vigna radiata, B. rapa subsp. pekinensis, Lepidium sativum, Trigonella \\
& foenum-graecum, L. sativa, Brassica nigra, A. sativa, Raphanus sativus, \\
& Trifolium pratense, Oryza sativa, Lo. perenne, Sorghum bicolor, B. rapa \\
& subsp. rapa, Vicia sativa, T. aestivum \\
& L. sativa, D. carota, Allium cepa, Z. mays, C. sativus, L. sativa, A. sativa, \\
& Lo. perenne, G. max, S. lycopersicum \\
& A. sativa (compulsory), B. rapa or B. rapa spp. rapa (compulsory), Z. \\
& mays, S. bicolor, Saccharum officinarum (optional)
\end{tabular}

Note: FDA (Food and Drug Administration, Washington DC), OECD (Organisation for Economic Cooperation and Development, Paris), USEPA (U.S. Environmental Protection Agency) and ISO (International Standardization Organization).

The primary disadvantage of using seed germination as a bioindicator assay of ecotoxicity is the plant intra- and inter species differential response to organic contaminants. Njoku et al. (2008) compared four accessions of Glycine max (soybean) and Lycopersicon esculentum (tomato) and found in each case only one or two accessions were suitable for germination and growth in crude oil contaminated soil treatments. In another experiment, they found that $\mathrm{EC}_{50}$ (effective concentration that caused 50\% decrease in germination) values for 10 accessions of Sorghum bicolor differed in the range of 5-19\% (Njoku et al. 2011). Siciliano et al. (1997) tested the bioindicator potential of 17 prairie grass species using a seed germination assay and found a 12-fold difference in their response towards 2-chlorobenzoic acid, an intermediate in the degradative pathway of polychlorinated aromatics. They noted the similarity between their results and those of the meta-analysis of Fletcher et al. (1990) who found an 11-fold difference among species in their response to herbicides. The data used by the latter were from the PHYTOTOX database, which consists of the response of plant species to organic contaminants 
and herbicides and, at the time of analysis, was a collation of 230 published studies using 151 species from 43 families. Although the mode of action of herbicides is different to other environmental contaminants, in the absence of substantial bio-assay literature on other organic contaminants, a correlative generalisation of results for extrapolation to non-standard species or test conditions is valid (Clark et al. 2004). Other reports found large differences among potential bioindicator plant species in their response to polychlorinated biphenyls (Meier et al. 1997), PAHs (Sayles et al. 1999) and heavy metals such as lead (Chang et al. 1997). In addition to the variability among species, another reason impeding the widespread use of germination bioassays is their lack of sensitivity compared with other commonly-used assays which use earthworms, bacteria, algae and enzymes. The placement of seed germination assays in a hierarchy of sensitivity with respect to other bioassays is controversial as it may vary with the contaminant. For example, the decreasing order of sensitivity towards heavy metals was algae > daphnids > bacteria > plant seeds > earthworms, while for herbicides it was plant seeds >> algae $=$ bacteria $>$ daphnids $>>$ earthworms (Miller et al. 1985; Thomas et al. 1986). Later, Dorn et al. (1998) showed that for three types of crude oil (light, medium and heavy) the order was earthworms > microtox solid-phase >> plant growth > seed germination, with earthworms 77 times more sensitive than seed germination. The influence of soil properties such as organic matter, clay, $\mathrm{pH}$ and temperature in such experiments has not been studied, making it difficult to differentiate plant effects from physical effects of contaminant and soil (Sayles et al. 1999). Therefore, it can be concluded that the results of seed germination bioassays for various contaminants, especially those with significantly different physical and chemical properties, may not be the most useful choice as a bioindicator for species in a particular scenario. Specific research is required on the toxicity of petrogenic contaminants under the relevant soil properties.

The suitability of a bioindicator plant species will depend on various factors such as soil, climate and species growth attributes. However, the most important prerequisite is that the measurement of its parameters (e.g. growth, emergence) must give interpretable response curves across a range of environmental parameters (Adema and Henzen 1989; Hund and Traunspurger 1994). Usually, this information is graphed as dose-dependent logarithmic response curves to calculate regression equations. The middle part of the curve is highly sensitive to contaminant concentration (Klassen and Eaton 1991) and using a bioindicator with an appropriate response range can help to predict toxicity levels (Siciliano et al. 1997). In the context of petrogenic hydrocarbons or their metabolites, only a few plant measurements (also 
known as 'endpoints') have been used to plot response curves. These are root elongation (BaudGrasset et al. 1993; Wang et al. 2001, 2002), shoot length (Reynoso-Cuevas et al. 2008), shoot biomass (Salanitro et al. 1997) and, most commonly, percent emergence (Baud-Grasset et al. 1993; Siciliano et al. 1997; Wang et al. 2001). The endpoints can be broadly classified as reproductive (seed production, seed viability, germination capacity, thousand-grain weight) or vegetative (shoot/root length and biomass) and the sensitivity of each is compound specific

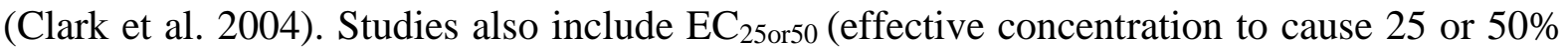
inhibition) values for plant species. One challenge with the use of laboratory tests is that they may not be ecologically meaningful as, in the field, the contaminant is likely to degrade at a different rate than in the laboratory (Wang and Freemark 1995); faster rates may result in the release of toxic metabolites (Chaineau et al. 1995; Phillips et al. 2000).

When considering the use of higher plants as opposed to other test organisms such as earthworms to assess ecotoxicity, it is logistically difficult to test multiple species with multiple petrogenic contaminants under multiple soil characteristics for the desired correlations. Nevertheless, higher plants have been advocated for toxicity assessments due to their ecological relevance in the food webs, and with a particular focus on germination and early growth for the reasons mentioned previously. More research is needed to determine the antagonistic, synergistic or additive nature of the metabolite-contaminant relationship so that proper corrections can be made to bioindicator calibration curves (Siciliano et al. 1997). Figure 3 shows the effect of increasing diesel concentrations on root growth in B. napus. Note that parameters such as root length cannot provide linear trends; however, with the help of imaging software like WinRhizo, more insightful measurements such as root surface area, average root diameter, the proportion of the root system in root diameter classes and the number of root tips and forks can be made. 


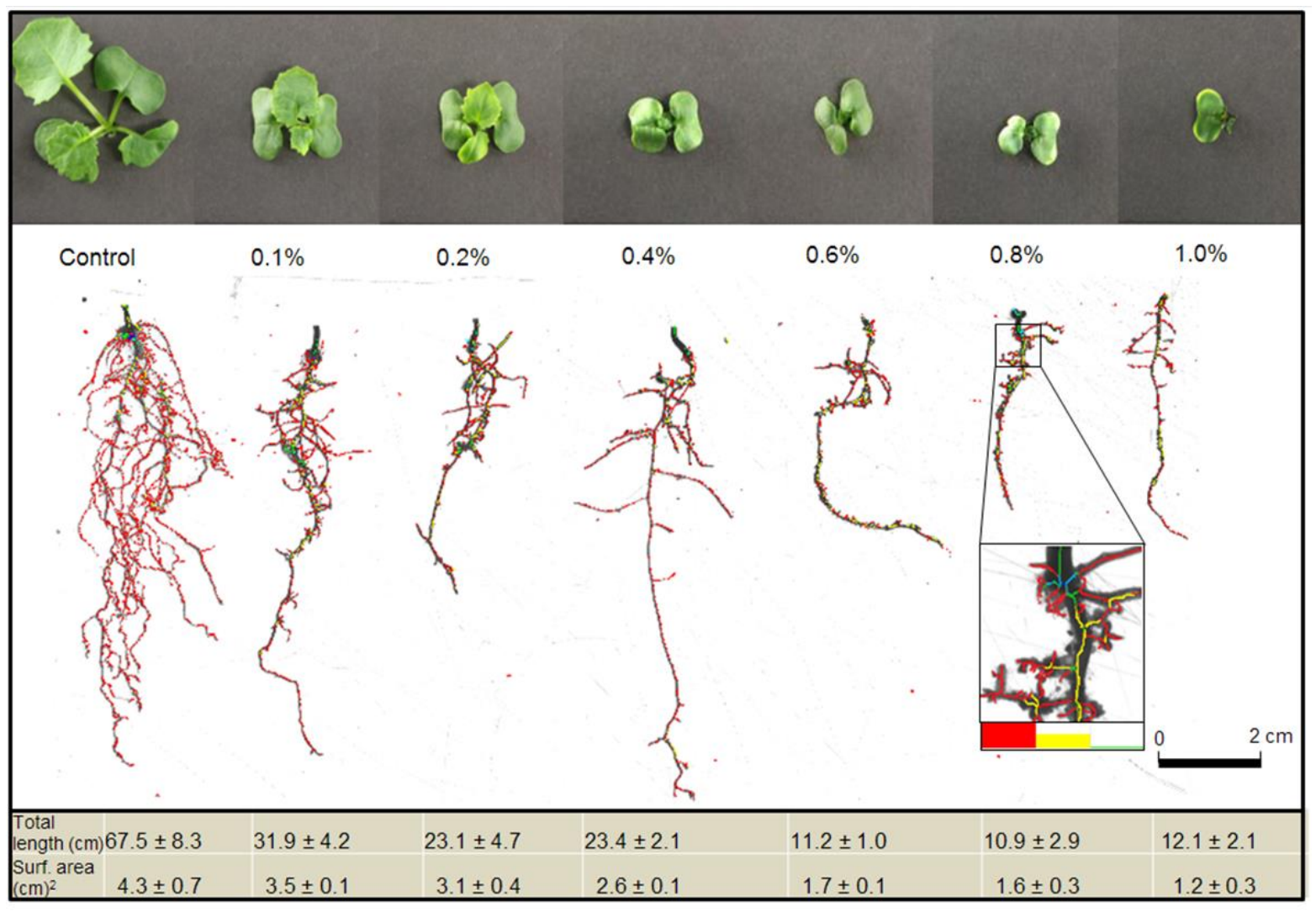

Fig. 3 The effect of increasing diesel contamination on shoot and root growth of Brassica napus grown in white sand for four weeks at $25^{\circ} \mathrm{C}$. Inset shows WinRhizo colour classification of root diameters as red, yellow and green for root diameters of $<0.5,0.5-1.0$ and $1.0-1.5 \mathrm{~mm}$, respectively. Values are means \pm s.e., $n=3$.

\section{Screening plant species for industrial and agricultural land use}

While industrial areas are more prone to oil spills (Maddock 2015), transporting oil in pipelines poses a huge contamination risk for agricultural areas (Corbin 2013). Most phytoremediation projects prefer to grow native plants on contaminated sites because of their innate adaptability to climate and soil conditions (Gerhardt et al. 2009; Kirk et al. 2002; Ogbo, 2009; ReynosoCuevas 2008). However, due to their complex germination requirements-such as speciesspecific temperature requirements, innate dormancy mechanisms and low seed viabilitynative species may be difficult to establish (Farley et al. 2013; Merritt et al. 2007). Also, some species take a long time to germinate, which may not be a successful strategy in freshlycontaminated soils as it may provide time for penetrative damage to the seed. Seeds of most cultivated plants, on the other hand, generally do not have primary dormancy and germinate rapidly. Correlation between germination time and penetrative damage may explain the results 
of Sharonova and Breus (2012) who tested 50 plant species and found that cultivated plants tolerated hydrocarbon contamination better than natives. It is also important to note that cultivated plants that have been hybridised to produce large seeds and high relative growth rates (i.e. Zea mays, Triticum aestivum, Glycine max) may respond differently to hydrocarbon contamination than those grown for fodder (i.e. Melilotus officinalis) (Elias and Chadwick 1979). Moreover, as per the recommendations of environmental organisations, readilyavailable agronomic species have often been used for phytoremediation because they are good bioindicators of toxicity for various types of contaminants, predominantly herbicides and pesticides (Table 4). Assessment of the most elaborate database, PHYTOTOX (currently more than 3500 published studies), showed that little to no data exist for species from grassland, desert, coniferous or other biomes outside the northern temperate zone and that the data are heavily biased for agronomic types (Clark et al. 2004). There are too few reports on plant responses to petrogenic hydrocarbons in this database to draw broad conclusive trends. Also, the relevance of these research outcomes to countries such as Australia is questionable, due to the significant differences in climate, soil type, endemic flora and environmental regulation criteria (Michael et al. 2007). Moreover, using cultivated plants for remote locations such as mining sites is not feasible because basic requirements such as water and fertiliser supplements may not be easily met. Considering that the relative suitability of native and cultivated plant species for revegetation strongly depends on the requirements of the contaminated site, more species need to be screened for phytoremediation suitability.

\section{Selection criteria - plant attributes and challenges}

Literature suggests that germination and the subsequent survival of a particular species in contaminated soil are independent and may not correlate with the ability of the species to initiate biodegradation (Besaltpour et al. 2008; Smith et al. 2006). Therefore, it is important to formulate selection criteria based on plant mechanisms that are known to maximise the biodegradation of TPH and PAH contamination in soils. The best approach may be a combination of the factors outlined below.

\subsection{Species phylogeny}

Plant species vary in their tolerance to contaminants. Indeed, significant differences have been found among varieties/cultivars of the same species. For example, Graj et al. (2013) noticed that a $B$. napus variety with high (40-60\%) erucic acid content in seed was better than a low $(2 \%)$ erucic acid variety in terms of germination index, root elongation and biomass production 
under contaminated conditions. Our results (Figure 1) show that species of Poaceae had the lowest germination when sown in diesel and high concentrations of crude oil compared with species from other families. Whether such differences can be explained by phylogeny was the topic of investigation in some recent meta-analyses. Collins and Willey (2009) ran a residual maximum likelihood analysis (REML) on data derived from ten studies incorporating 75 species. The shoot and root dry weight data were converted to a tolerance index (TI) with reference to controls with no contamination as $\mathrm{TI}=1$. They also ran separate models to account for root and shoot uptake of organic contaminants by converting the data to RCF (root concentration factor) and SCF (shoot concentration factor). Notably, Asterales and Brassicales were the most tolerant orders, with order and genus levels accounting for $54 \%$ of the $78 \%$, respectively, of the variation accounted for by the model. Further, monocots were more sensitive than eudicots and the order Poales (consists of family Poaceae) was one of the most sensitive orders. This suggests that many grass species, although desirable for their high root density, may be more difficult to establish on contaminated sites than other clades. The species with the most tolerance to contamination were Helianthus annuus, L. sativa and Salvia officinalis. Daucus carota was mentioned in the study above and elsewhere (Adam and Duncan 2002) as tolerant of organic chemicals as herbicides; it belongs to the order Apiales under the same superorder, Asterid 2, as Asterales. Consistent with this, we found that emergence of Rhodanthe chlorocephala (Asterales) was the highest of all tested species at $1.5 \%$ diesel contamination (Fig. 1).

A more targeted meta-analysis was done by Ma et al. (2010) on data from 41 studies which measured the biodegradation of PAHs in the rhizosphere. In total, 668 comparisons of 51 species were made; the families Alliaceae and Amaranthaceae exhibited the highest biodegradation. The authors suggested that because plants in these families released aromatic compounds into the rhizosphere, they were likely to stimulate degraders more effectively. These compounds, known as plant-derived biosurfactants, increase the bioavailability (lability) of PAHs for microbial breakdown, causing enhanced biodegradation. For example, artificial and natural saponins from Chinese soapberry (Sapindus mukorossi) increased phenanthrene desorption in lab-based incubation experiments (Zhou et al. 2011, 2013) and the application of cyclodextrins from maize (Z. mays) caused tetrachloroethene degradation (Adani et al. 2010). The occurrence of some aromatic compounds in plants such as flavonoids, terpenes and alkaloids, serves an important role in plant defence mechanisms (Wink 1988). Naturally, seeds of such plants germinate in soils enriched with the litter of similar plant(s) and, therefore, may 
possess specialised strategies to limit damage from hydrocarbons or enhance biodegradation of hydrocarbons via microbiological pathways.

The above examples suggest that phylogeny may be a useful way to identify species with bioremediation potential. Table 5 summarises survey reports of species present at contaminated sites; note that Poaceae, Asteraceae and Amaranthaceae are the dominant plant families. As discussed earlier (and evident in Figure 1), while Poaceae may be sensitive at germination and/or subsequent growth stages, and possibly more so in freshly-contaminated soils, it may emerge later on a contaminated site due to successional changes after species from more tolerant families are established. It is plausible that the effective species in the initial stages of bioremediation, when aliphatic compounds are high in concentration, do not remain beneficial at later stages when aromatic recalcitrant compounds persist. The evolutionary basis for why plants of some families/genera are more tolerant than others has not been studied using molecular techniques and reports on the differences in germination response to PAHs on plant families are elusive. More research on these aspects would benefit future screening studies.

Table 5 Plant families that grow at sites contaminated with petrogenic hydrocarbons

\begin{tabular}{|c|c|}
\hline Site survey & Plant families \\
\hline Anoliefo et al. 2006 & $\begin{array}{l}\text { (*11- Poaceae }),(8-\text { Asteraceae }),(5-\text { Euphobiaceae }),(4- \\
\text { Amaranthaceae, Caesalpiniacea, Cyperaceae), }(2-\text { Malvaceae, } \\
\text { Piperaceae, Portulaceae, Rubiaceae, Solanaceae, Urtinaceae), (1- } \\
\text { Araceae, Asystasiae, Bromeliaceae, Bignoniaceae, Crassulaceae, } \\
\text { Capparaceae, Chlorideae, Caricaceae, , Fabaceae, Ficeae, } \\
\text { Lamiaceae, Loganiceae, Musaceae, Nyctaginacea, Spermacoceae, } \\
\text { Vernonieae) }\end{array}$ \\
\hline Henn & $\begin{array}{l}\text { (6- Asteraceae), (4 - Poaceae), (3 - Brassicaceae), }(2- \\
\text { Amaranthaceae, Crassulaceae, Onagraceae, Solanaceae), (1- } \\
\text { Apiaceae, Boraginaceae, Betulaceae, Caryophyllaceae, } \\
\text { Hypericaceae, Loganiaceae, Papaveraceae, Ranunculaceae, } \\
\text { Rosaceae, Verbasceae, Salicaceae })\end{array}$ \\
\hline $\begin{array}{l}\text { Olson and Fletcher } \\
2000\end{array}$ & $\begin{array}{l}(15 \text { - Asteraceae }),(13 \text { - Poaceae }),(3-\text { Verbenaceae }),(2- \\
\text { Amaranthaceae, Fabaceae }),(1 \text { - Brassicaceae, Campanulaceae, } \\
\text { Capriloliaceae, Cucurbitaceae, Cyperaceae, Euphorbiaceae, } \\
\text { Geranlaceae, Moraceae, Phytolaccaceae, Ranunculaceae } \\
\text { Rubiaceae, Solanaceae, Typhaceae, Ulmaceae, Urhcaceae, } \\
\text { Vitaceae })\end{array}$ \\
\hline $\begin{array}{l}\text { Gudin and Syratt } 1975 \\
\text { Robson et al. } 2004 b\end{array}$ & $\begin{array}{l}\text { Poaceae, Fabaceae, Asteraceae, others (surveyed by \% cover) } \\
(10-\text { Poaceae }),(4-\text { Asteraceae }),(1-\text { Amaranthaceae, } \\
\text { Cyperaceae, Caprifoliaceae, Rosaceae })\end{array}$ \\
\hline
\end{tabular}

*Number of plant species recorded from a particular family 


\subsection{Plant morphological traits}

Microbial populations in the rhizosphere can be several orders of magnitude higher $\left(10^{2}-10^{4}\right)$ than bulk soil (Hinsinger et al. 2005; Macek et al., 2000; Siciliano and Germida 1998) as the rhizosphere provides stimulating conditions for soil microbes (discussed later, $i i i$ and $i v$ ). The study by Aprill and Sims (1990) is often cited to illustrate that a high root surface area is a key factor for boosting plant-microbe interactions. However, this may be oversimplified and other root architecture traits, such as those associated with efficient nutrient foraging, could play a more decisive role. Both plant access to nutrients and remediation of hydrocarbons by rhizosphere microbial populations will increase with the proportion of soil volume that is in the rhizosphere. The volume of rhizosphere soil can be considered as a cylinder and calculated simply as a function of total root length (height) and root hair length (radius), i.e. $\pi r^{2} h$ (Haling et al. 2016; Yang et al. 2015). The best approach for a plant to maximise the volume of rhizosphere soil, in terms of the energy required for root production, is production of a long length of thin roots with long root hairs (Haling et al. 2016; Yang et al. 2015). The extensive fibrous root systems produced by members of the Poaceae are an example of such root systems and in experimentally-contaminated soils species of Poaceae often have the highest remediation potential (Gaskin and Bentham 2010; Gunther et al. 1996; Olson et al. 2007a; Reilley et al. 1996). A desirable attribute discussed by many authors is a high rate of shoot and root biomass production (Adam and Duncan 2002; Gaskin et al. 2008). In addition to the fast production of a large volume of rhizosphere soil, rapid root development will increase water uptake for evapotranspiration and nutrient acquisition and, for some species, enable the translocation of derivatives of parent-compound degradation from the roots to aboveground parts thus reducing the overall amount in the soil via in planta mechanisms (Wang et al. 2012).

Insoluble organic compounds are also incorporated into the plant transpiration stream (Kamath et al. 2004; Licht and Isebrands 2005). In this regard, various tree species such as poplars (Populus sp.), mulberry (Morus sp.) and willow (Salix sp.) have been successfully trialled for use in contaminated soils (Kamath et al. 2004). Mature poplar trees have an impressive transpiration capacity of 200-1000 litres of water per day (Pilon-Smits 2005). Tree roots have been reported to reach depths of up to $15 \mathrm{~m}$ (Pilon-Smits 2005) which is, obviously, useful when remediating contamination from beneath surface layers as the roots of herbaceous species typically only reach $100 \mathrm{~cm}$ (annuals) to $200 \mathrm{~cm}$ (perennials) depth (Bell et al. 2006). As previously mentioned, the presence of hydrocarbon contaminants often deters plant growth, with the roots more severely affected than shoots. Despite this, important root characteristics 
related to fitness and survival such as total root length, average diameter, root hair length and frequency, and root to shoot ratio have not been well investigated in regards to their effects on biodegradation. In a recent study by Hernández-Ortega et al. (2014), roots of 10-day-old Medicago sativa seedlings lost their tetrarch vascular arrangement when the number of metaxylem vessels increased under diesel stress. As a result, root hydraulic conductivity declined significantly. Interpretations such as this can be useful in selecting species that perform well post-emergence in contaminated environments. It is, however, important to remember that these characteristics vary depending on environmental factors such as water availability, nutrients, soil physical properties and temperature. Also, the overall response to these physical factors, and the growth and development of roots, is largely governed by the genetic make-up of the plant species or variety (Hutchison et al. 2003).

\subsection{Fabaceae - for prospective candidates}

To deduce mechanistic pathways, numerous studies have attempted to explain successful phytoremediation outcomes in the light of the functional traits of the plants used. Root nodulation by members of Fabaceae (legumes) is a notable example. In contaminated-soil environments, the ability to fix nitrogen is considered highly advantageous because the carbon to nitrogen ratio becomes imbalanced due to the presence of hydrocarbons (Lee et al. 2008; Palmroth et al. 2002; Parrish et al. 2005). Under natural conditions, Fabaceae plants are often the pioneering species at disturbed sites (Gudin and Syratt 1975), but have mostly been used as comparative plants (Hall et al. 2011). Microorganisms of genera such as Rhizobium, Bradyrhizobium, Sinorhizobium, Azospirillum, Azotobacter and Frankia can make symbiotic associations (nodules) with plant roots and can fix atmospheric nitrogen as ammonia (Graham and Vance 2000). Fabaceae, the third largest terrestrial plant family, consists of around 19,000 species (Giller 2001). Of the limited number studied so far, more than $90 \%$ of two of the three subfamilies (Papilionoideae, Caesalpinioideae and Mimosoideae) form nodules (Giller 2001). Since the advent of phytotechnologies, only a few legume species have been tested; however, the most widely studied are from Medicago and Trifolium genera and these are effective at bioremediation (Figure 4). Nichols et al. (1997) found that for every gram of rhizosphere soil, the counts of microbial degrader populations for inoculated Medicago sativa were four times more than those for the grass Poa alpina, when grown in soil spiked with a mixture of synthetic compounds found in crude oil. Similar reports have been discussed in a review by Hall et al. (2011). Hall et al. (2011) support the use of Fabaceae for hydrocarbon bioremediation because they can improve: (i) soil structure and aeration by tap root penetration, (ii) soil $\mathrm{N}$ status by 
biological fixation, (iii) plant access to $\mathrm{P}$ by forming symbiotic associations with arbuscular mycorrhizal fungi (AMF), and (iv) contaminant bioavailability by releasing biosurfactants and other carbonaceous compounds from roots. It should, however, be noted that legumes may depend heavily on AMF for $\mathrm{P}$ uptake as the hyphae explore soil outside the rhizosphere (Jakobsen et al. 1992). Most grass species can also be colonised by AMF (O'Connor et al. 2001), but may not rely so heavily on the fungi for accessing $\mathrm{P}$ due to their fibrous root system (see $i$ ).

\subsection{Root exudates - common and specialised}

Many recent studies in the area of rhizoremediation and rhizosphere biology have focussed on the range of substances exuded by roots, such as sugars, amino acids, proteins, mucilage and organic acids. Known as the rhizosphere effect, it is speculated that these exudates are responsible for selecting specific type(s) and possibly quantitative numbers of microbial communities to proliferate in the vicinity of the plant roots (Kirk et al. 2005; Joner et al. 2002; Macek et al. 2000). About 30-60\% of photosynthates are transferred to the roots, $10-20 \%$ of which can be released in rhizodeposition (Marschner 1995). One of the most abundant exudates are the carboxylic acids. Since they have low molecular weights and presumably provide a labile source of carbon for microbes, they have been hypothesised to play a key role in stimulating biodegradation rates (Louvel et al. 2011; Martin et al. 2014; Rentz et al. 2005). With an increase in phytoremediation candidates in the future, such interactions need to be investigated at the greenhouse and field scale. The feasibility of screening seedlings for exudation rate is, however, an area that requires investigation. The amount of rhizosphere carboxylates may differ with seedling age, and not in a consistent manner among species (Suriyagoda et al. 2012). Moreover, exudation may be greatly influenced by biotic and abiotic factors such as presence of mycorrhizal fungi, soil type and water and nutrient availability (Ryan et al. 2014; Suriyagoda et al. 2012).

A review by Singer et al. (2003) presented an interesting case for the use of plant produced/exuded secondary metabolites for biodegradation. The authors postulated that due to the similarities in the chemical structure of hydrocarbons (branched or aromatics) and naturally-occurring plant metabolites such as flavonoids, terpenoids, and coumarins, the latter can be used to induce the genes responsible for the production of degenerative enzymes. Considering the reported heterogeneity of degradative pathways among microbial systems (Bogan et al. 2001), this new area of research would have significant benefit if the relevant 
species were trialled in screening experiments. In the literature, studies on the effects of plantderived extracellular enzymes such as nitroreductases, dehalogenases, laccases and dehydrogenases are limited but have shown promise in both laboratory and field experiments (Wenzel 2009). For example, nitroreductase and laccase enzymes break down TNT $(2,4,6-$ trinitrotoluene), dehalogenase aids the removal of chlorine from TCE (trichloroethylene), and peroxidases degrade phenols and phosphatases can cleave phosphate groups from organophosphate pesticides (Schnoor et al. 1995; Susarla et al. 2002). Again, the analogy between the chemical structures of these compounds and that of petrogenic contaminants may be applicable for enhancing biodegradation mechanistically.

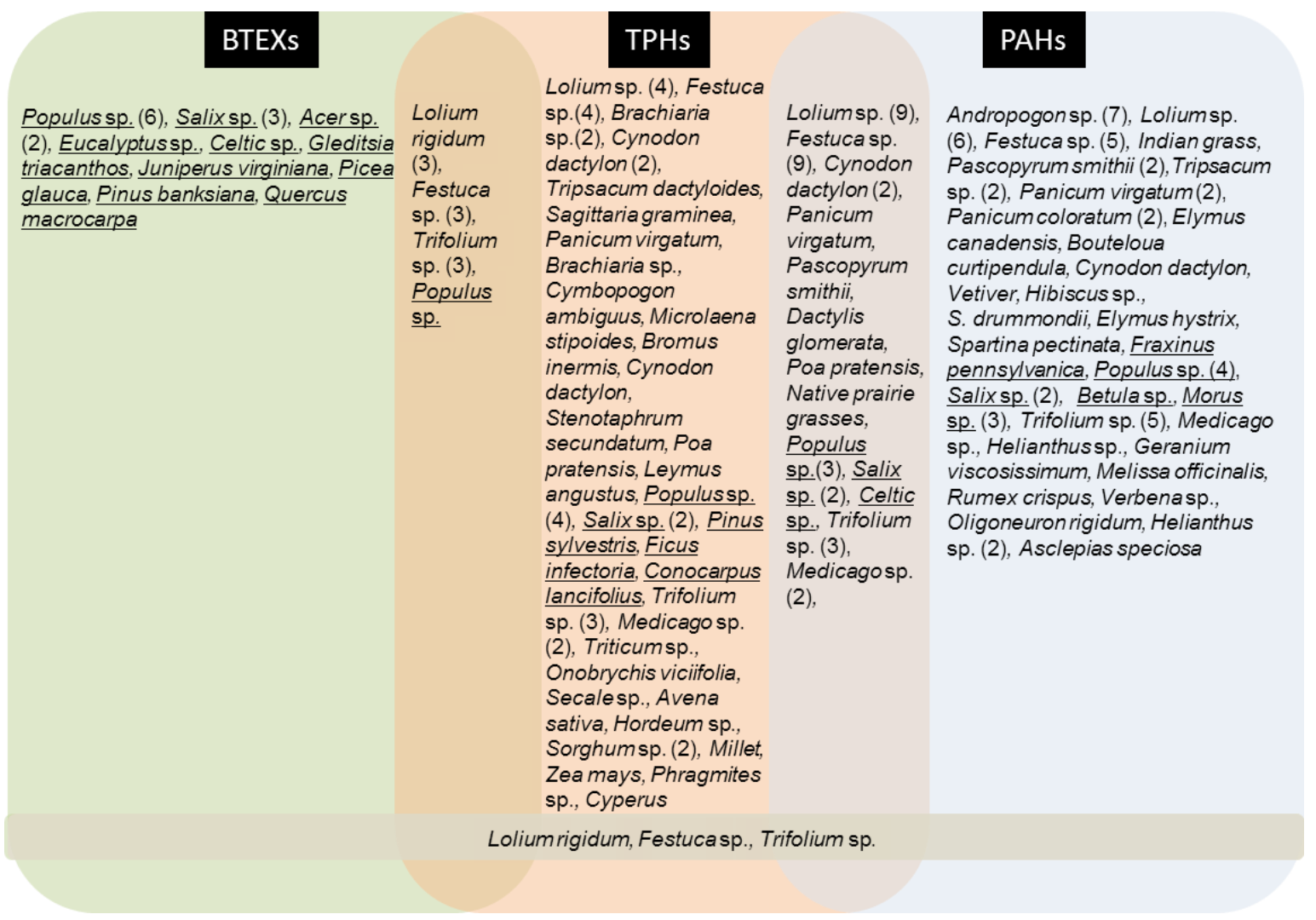

Fig. 4 A representation of the plant species (grasses, trees (underlined), legumes and forbs) used for rhizoremediation from the early 1990 s to 2013 . The value in parentheses is the number of times a species has been grown in studies involving an individual contaminant type or comparative studies containing two or three contaminant types - TPHs (total petroleum hydrocarbons), BTEXs (benzene toluene, ethylbenzene, xylene) and PAHs (polycyclic aromatic hydrocarbons) (adapted information; for common names and reference studies see Appendix 1 of Cook and Hesterberg (2013)). 


\subsection{Tolerance towards harsh environmental stresses}

As discussed earlier, the presence of hydrophobic petrogenic contaminants creates low permeability and infiltration of water into the soil. As a consequence, patches of water saturation and artificial drought can occur simultaneously in the soil profile. Roots of plants that are tolerant to such variable soil conditions are essential for creating macropores in the subsurface layers. Macropores not only facilitate the movement of water and nutrients but also improve aeration and the availability of oxygen to stimulate microbial activity, thus increasing biodegradation (Hutchinson et al. 2001). Plant roots can also oxidise the rhizosphere directly. In a review by Shimp et al. (1993), specific strategies are discussed about how trees and plants that are flood-tolerant or adapted to wetlands, transfer more oxygen into the rhizosphere, stimulating the biodegradation of organic contaminants. They suggested that flood tolerance is an inverse function of alcohol dehydrogenase enzyme activity. However, morphological adaptations to the low oxygen conditions under waterlogging may also aid survival in contamined soils. For example, the formation of adventitious roots, an unsuberized epidermis and the degeneration of the Casparian strip, and the formation of lenticles (e.g. Salix alba) to release into air toxic metabolites such as ethanol, acetaldehyde and ethylene (Colmer and Flowers 2008; Shimp et al. 1993). As much as $0.5 \mathrm{~mol} \mathrm{O}_{2} \mathrm{~m}^{-2}$ soil surface per day is reportedly released by roots (references in Shimp et al. 1993). Thus, it is possible that plant adaptations to the low oxygen conditions caused by waterlogging may provide an advantage for growth under hydrocarbon contamination, but only if the plant is otherwise well-adapted to the growing conditions.

The identification of plant species which have biodegradation potential and can tolerate moisture limitations will be important, especially for semi-arid and arid areas such as in Western Australia and Persian Gulf countries. Water is essential for microbial growth and mobility, and to alleviate nutrient limitation or toxicity to plants at high water potentials (Walworth et al. 1997). Across different soils, a water-filled porosity between 20 and $80 \%$ has increased hydrocarbon biodegradation rates (Tibbett et al. 2011). Moreover, contaminated sites are frequently associated with high levels of salinity, exhibiting electrical conductivities above $4 \mathrm{dS} \mathrm{m}^{-1}$ (Hutchinson et al. 2003; Robson et al. 2004b). Soils with conductivities above $2 \mathrm{dS}$ $\mathrm{m}^{-1}$ are considered salt-affected; therefore, the compilation of a list of salt-resistant plant species would assist proper site management (Hutchinson et al. 2003). Ultimately, soil effects and topography regulate the abiotic stress faced by plants. Properties such as bulk density, soil 
texture, hydraulic conductivity and the level of the water table should also be considered before making decisions on which species should be trialled (Hutchinson et al. 2003). For a particular site, useful information on relevant plant species can be obtained from local experts such as seed suppliers (Hutchinson et al. 2003) and surveys of indigenous vegetation accrued as a result of ecological succession (Olson and Fletcher 2000; Robson 2003). Most non-agricultural contaminated sites are low-nutrient systems, and such records will help to target species that are well adapted to particular site conditions (Table 5). Therefore, the selection of native species is likely to be advantageous.

\section{Recommendations - a prototype of improved germination protocols}

Many authors agree that determination of the most efficient plant species for biodegradation is the most important step in the field of phytoremediation (Graj et al. 2013; Macek et al. 2000; Yateem et al. 2007). It is, therefore, necessary to compile known and future research outcomes to improve screening experiments. In this regard, a major problem is the lack of standardised protocols, as the results of most experiments cannot be generalised or usefully compared due to the complexity generated by factors such as methodology, environment, soils and plant species. To address this issue, below is a list which could enable better control of treatment conditions.

a. When reporting results, authors must be clear about plant life stages, especially regarding germination versus emergence which are two distinct events (James et al. 2013) and will produce different results when comparing species, contaminants and experimental approaches (e.g. Petri dish versus pot studies).

b. The categorisation of contamination levels done by Gilyazov and Gaisin (2003) is useful. Other studies have used the same scale to divide contamination into four levels-low $(0.5$, 1 and 2 wt. \%), medium (3 and 5 wt. \%), high (10 wt. \%) and very high (15 wt. \%) - and applied the same as parameters for modelling differences in plant species (Potashev et al. 2014; Sharonova and Breus 2012). Conforming to this categorisation would help future inter/intra-studies modelling assignments.

c. The use of filter papers should be avoided. Other substances in soil such as humic acids, organic matter and clay particles can also sorb PAHs. The use of washed white sand as a growth medium can reduce these confounding effects in different types of soils and is easily sterilised to remove microbial communities.

d. The use of plastic Petri dishes should also be avoided. 
e. Petri dishes (plastic or glass) have a limited depth which means that large seeds may not be fully covered with the contaminated medium. The use of deeper containers would likely result in less variation in germination and emergence. Also, trials could be extended by a few weeks to allow assessment of seedling survival and the collection of more plant growth data.

f. Proper ventilation arrangements should be in place when using open Petri dishes. Highmolecular-weight pure petrogenic compounds such as anthracene, phenanthrene and pyrene are less volatile at room temperature and can, therefore, be used in closed Petri dishes.

g. Some studies use few seeds per replicate and/or few replicates. It is advisable to use a minimum of 25 seeds and four replicates (Martyn et al. 2009). For smaller-seeded species, more seeds per replicate can be used (e.g. 75-100 per replicate).

h. Seed viability is a concern, especially with native seeds. Various tests such as tetrazolium staining and floatation can be used to separate non-viable seeds a priori. More recently, Xray analysis has provided an alternative viability assessment option and is a rapid and nondestructive method applicable to a wide range of native species (Erickson and Merritt 2016). Species naturalised or native to a site evolve based on natural climatic conditions and thus inculcate dormancy mechanisms which break only upon survival of precise conditions to ensure species survival.

i. Remediation of hydrocarbon-contaminated soils is not usually achieved within one growing season. Native plants that require minimal maintenance (e.g. fertilisers, pruning, watering) should be considered. The low-nutrient status of most contaminated sites may enhance plant requirements for the establishment of a sustainable vegetation cover (Harris et al. 1996). Continual plant growth depends on various factors such as competition, abiotic/biotic seed dispersal processes and seasonal drought cycles along with other management-related issues. Many of these problems can be addressed by selecting the correct plant species. For predicting the trajectory of successional outcomes following the restoration of degraded areas, James et al. (2013) proposed the use of a system-based approach which means that, in hierarchical models, some ecological processes should be given more importance than others depending on the specific requirements of a site (system).

j. Easy to measure physiological indexes such as leaf and root area have been largely ignored. These, coupled with other physiological parameters such photosynthetic ability and root/leaf respiration using equipment such as LiCOR, can yield important results for unravelling the mechanisms that ensure better plant survival and possibly, germination. 
k. We suggest that root architectural traits that confer a large volume of rhizosphere soil, i.e., long thin roots with long root hairs, may be indicative of a high bioremediation potential and could be easily used to screen seedlings.

\section{Conclusions}

At the time of dormancy release, germination is controlled by multiple, often interacting, abiotic and biotic factors, which are influenced by the presence of hydrocarbons. The complication ensued by the differences among contaminants, their bioavailability and ecotoxicity at varying levels, produces variation in the response among plant species, which is also highly dependent on phylogenetic relationships at a species, genus and family level. In the literature, there is a generalised trend of screening species that belong to Poaceae and Fabaceae only. Our review of hydrocarbon contamination studies is not conclusive as to whether the species from these two families germinate better than those from other families. Whether germination results can be used as an added criterion for plant selection is questionable, as some plants may germinate well, but suffer toxicity post-emergence or be unsuited to growth conditions in the field. Nonetheless, germination studies are beneficial for deciding which species can be ruled out from further research. The standardisation of germination and emergence protocols will enable stronger inferences from meta-analyses and models, and will help to assess phylogenetically closely-related plant species.

\section{Acknowledgements}

This work was funded by an Australian Research Council linkage project (LP110201130) in partnership with Horizon Power, ChemCentre WA and Environmental Earth Sciences. Navjot Kaur holds Australian Post-graduate Award and Megan Ryan is funded by an ARC Future Fellowship (FT140100103).We thank Charles Price and Jason Stevens for useful discussions about the germination trials. 


\section{References}

Achuba, F., 2006. The effect of sublethal concentrations of crude oil on the growth and metabolism of cowpea (Vigna unguiculata) seedlings. Environmentalist 26, 17-20.

Adam, G., Duncan, H., 1999. Effect of diesel fuel on growth of selected plant species. Environmental Geochemistry and Health 21, 353-357.

Adam, G., Duncan, H., 2002. Influence of diesel fuel on seed germination. Environmental Pollution 120, 363-370.

Adani, F., Tambone, F., Davoli, E., Scaglia, B., 2010. Surfactant properties and tetrachloroethene (PCE) solubilisation ability of humic acid-like substances extracted from maize plant and from organic wastes: A comparative study. Chemosphere 78, 1017-1022.

Adema, D., Henzen, L., 1989. A comparison of plant toxicities of some industrial chemicals in soil culture and soilless culture. Ecotoxicology and Environmental Safety 18, 219-229.

Adenipekun, C.O., Oyetunji, O.J., Kassim, L.S., 2008. Effect of spent engine oil on the growth parameters and chlorophyll content of Corchorus olitorius Linn. The Environmentalist 28, 446-450.

Ahammed, G.J., Wang, M.M., Zhou, Y.H., Xia, X.-J., Mao, W.H., Shi, K., Yu, J.Q., 2012. The growth, photosynthesis and antioxidant defense responses of five vegetable crops to phenanthrene stress. Ecotoxicology and Environmental Safety 80, 132-139.

Alkio, M., Tabuchi, T.M., Wang, X., Colón-Carmona, A., 2005. Stress responses to polycyclic aromatic hydrocarbons in Arabidopsis include growth inhibition and hypersensitive response-like symptoms. Journal of Experimental Botany 56, 2983-2994.

Amakiri, J., Onofeghara, F., 1984. Effects of crude oil pollution on the germination of Zea mays and Capsicum frutescens. Environmental Pollution Series A, Ecological and Biological 35, 159-167.

Anoliefo, G., Ikhajiagbe, B., Okonofhua, B., Diafe, F., 2006. Eco-taxonomic distribution of plant species around motor mechanic workshops in Asaba and Benin City, Nigeria: Identification of oil tolerant plant species. African Journal of Biotechnology 5, 1757-1762.

Aprill, W., Sims, R.C., 1990. Evaluation of the use of prairie grasses for stimulating polycyclic aromatic hydrocarbon treatment in soil. Chemosphere 20, 253-265.

Atlas, R.M., 1991. Microbial hydrocarbon degradation - bioremediation of oil spills. Journal of Chemical Technology and Biotechnology 52, 149-156.

ATSDR, 1999. Report Toxicological profile for total petroleum hydrocarbons. U.S. Department of Health and Human Services. Public Health Service Agency for Toxic Substances and Disease Registry.

Baker, J.M., 1970. The effects of oils on plants. Environmental Pollution 1, 27-44.

Baker, J.M., 1971. Growth stimulation following oil pollution, in: Cowell, E.B. (Ed.), The Ecological Effects of Oil Pollution on Littoral Communities. Applied Science Publishers Ltd., Barking, England, pp. 72-77.

Baldwin, I., 1922. Modification of the soil flora induced by applications of crude petroleum. Soil Science 14, 465-478.

Banks, M., Schultz, K., 2005. Comparison of plants for germination toxicity tests in petroleumcontaminated soils. Water, Air, and Soil Pollution 167, 211-219.

Baud-Grasset, F., Baud-Grasset, S., Safferman, S.I., 1993. Evaluation of the bioremediation of a contaminated soil with phytotoxicity tests. Chemosphere 26, 1365-1374.

Bell, L.W., Ryan, M.H., Moore, G.A., Ewing, M.A., 2006. Comparative water use by Dorycnium hirsutum-, lucerne-, and annual-based pastures in the Western Australian wheatbelt. Crop and Pasture Science 57, 857-865. 
Besalatpour, A., Khoshgoftarmanesh, A., Hajabbasi, M., Afyuni, M., 2008. Germination and growth of selected plants in a petroleum contaminated calcareous soil. Soil \& Sediment Contamination 17, 665-676.

Bewley, J.D., Black, M., Halmer, P. (Eds) 2006. The Encyclopedia of Seeds: Science, Technology and Uses. CABI Publishing, Wallingford, UK and Cambridge, USA.

Binet, P., Portal, J., Leyval, C., 2000. Dissipation of 3-6-ring polycyclic aromatic hydrocarbons in the rhizosphere of ryegrass. Soil Biology and Biochemistry 32, 20112017.

Bogan, B.W., Lahner, L.M., Paterek, J.R., 2001. Limited roles for salicylate and phthalate in bacterial PAH bioremediation. Bioremediation Journal 5, 93-100.

Bona, C., Rezende, I.M., Santos, G.O., Souza, L.A., 2011. Effect of soil contaminated by diesel oil on the germination of seeds and the growth of Schinus terebinthifolius Raddi (Anacardiaceae) Seedlings. Brazilian Archives of Biology and Technology 54, 13791387.

Bossert, I., Bartha, R., 1985. Plant growth in soils with a history of oily sludge disposal. Soil Science 140, 75-77.

Boutin, C., Elmegaard, N., Kjaer, C., 2004. Toxicity testing of fifteen non-crop plant species with six herbicides in a greenhouse experiment: implications for risk assessment. Ecotoxicology 13, 349-369.

Brandt, R., Merkl, N., Schultze-Kraft, R., Infante, C., Broll, G., 2006. Potential of vetiver (Vetiveria zizanioides (L.) Nash) for phytoremediation of petroleum hydrocarboncontaminated soils in Venezuela. International Journal of Phytoremediation 8, 273-284.

Calabrese, E.J., 2005. Paradigm lost, paradigm found: the re-emergence of hormesis as a fundamental dose response model in the toxicological sciences. Environmental Pollution $138,378-411$.

Carr, R., 1919. Vegetative growth in soils containing crude petroleum. Soil Science 8, 67-68.

Chaineau, C.-H., Morel, J.-L., Oudot, J., 1995. Microbial degradation in soil microcosms of fuel oil hydrocarbons from drilling cuttings. Environmental Science \& Technology 29, $1615-1621$.

Chaineau, C., Morel, J., Oudot, J., 1997. Phytotoxicity and plant uptake of fuel oil hydrocarbons. Journal of Environmental Quality 26, 1478-1483.

Chang, A., Granato, T., Page, A., 1992. A methodology for establishing phytotoxicity criteria for chromium, copper, nickel, and zinc in agricultural land application of municipal sewage sludges. Journal of Environmental Quality 21, 521-536.

Chang, L.W., Meier J.R., Smith, M.K., 1997. Application of plant and earthworm bioassays to evaluate remediation of a lead-contaminated soil. Archives of Environmental Contamination and Toxicology 32, 166-171.

Chen, L., Liu, X., Zhang, X., Liu, S., Wei, J., Xu, G., 2013. Response characteristics of seed germination and seedling growth of Acorus tatarinowii under diesel stress. Plant and Soil 368, 355-363.

Chigbo, C., Batty, L., 2013. Effect of combined pollution of chromium and benzo (a) pyrene on seed growth of Lolium perenne. Chemosphere 90, 164-169.

Clark, J., Ortego, L.S., Fairbrother, A., 2004. Sources of variability in plant toxicity testing. Chemosphere 57, 1599-1612.

Cofield, N., Banks, M.K., Schwab, A.P., 2008. Lability of polycyclic aromatic hydrocarbons in the rhizosphere. Chemosphere 70, 1644-1652.

Collins, C., Fryer, M., Grosso, A., 2006. Plant uptake of non-ionic organic chemicals. Environmental Science \& Technology 40, 45-52.

Collins, C.D., Willey, N.J., 2009. Phylogenetic variation in the tolerance and uptake of organic contaminants. International Journal of Phytoremediation 11, 623-639. 
Colmer, T.D., Flowers, T.J., 2008. Flooding tolerance in halophytes. New Phytologist 179, 964-974.

Colwell, R.R., Walker, J.D., Cooney, J.J., 1977. Ecological aspects of microbial degradation of petroleum in the marine environment. CRC Critical Reviews in Microbiology 5, 423445.

Cook, R.L., Hesterberg, D., 2013. Comparison of trees and grasses for rhizoremediation of petroleum hydrocarbons. International Journal of Phytoremediation 15, 844-860.

Corbin, C., 2013. North Dakota farmer makes crude discovery: largest oil spill on US soil, FOX News. USA. http://www.foxnews.com/us/2013/10/15/oil-unwelcome-discoveryfor-north-dakota-farmer.html. Retrieved 30 March 2016.

Corgié, S., Beguiristain, T., Leyval, C., 2004. Spatial distribution of bacterial communities and phenanthrene degradation in the rhizosphere of Lolium perenne L. Applied and environmental microbiology 70, 3552-3557.

Daniel-Kalio, L., Pepple, S., 2006. Effect of bonny light crude oil pollution of soil on the growth of dayflower (Commelina benghalensis L.) in the Niger Delta, Nigeria. Journal of Applied Sciences and Environmental Management 10, 111-114.

De Jong, E., 1980. The effect of a crude oil spill on cereals. Environmental Pollution Series A, Ecological and Biological 22, 187-196.

Diao, C., Zhou, Q., Zhou, J.L., 2011. Growth responses and phytoremediation characteristics of Mirabilis jalapa L. in benzo [a] pyrene and pyrene co-contaminated soils, in: Jin, D., Lin, S. (Eds.), Advances in Computer Science, Intelligent System and Environment. Springer-Verlag, Berlin Heidelberg, pp. 397-403.

Dibble, J., Bartha, R., 1979. Effect of environmental parameters on the biodegradation of oil sludge. Applied and Environmental Microbiology 37, 729-739.

Dimitrow, D., Markow, E., 2000. Behaviour of available forms of NPK in soils polluted by oil products. Poczwoznanie. Agrochimija I Ekologia 35, 3-8.

Dong, T.T., Lee, B.K., 2009. Characteristics, toxicity, and source apportionment of polycylic aromatic hydrocarbons (PAHs) in road dust of Ulsan, Korea. Chemosphere 74, 12451253.

Dorn, P.B., Salanitro, J.P., 2000. Temporal ecological assessment of oil contaminated soils before and after bioremediation. Chemosphere 40, 419-426.

Dorn, P.B., Vipond, T.E., Salanitro, J.P., Wisniewski, H.L., 1998. Assessment of the acute toxicity of crude oils in soils using earthworms, microtox ${ }^{\circledR}$, and plants. Chemosphere 37 , $845-860$.

Elias, C., Chadwick, M., 1979. Growth characteristics of grass and legume cultivars and their potential for land reclamation. Journal of Applied Ecology, 537-544.

Erickson, T.E., Merritt, D.J., 2016. Seed collection, cleaning, and storage procedures, in: Erickson, T.E., Barrett, R.L., Merritt, D.J., Dixon, K.W. (Eds.), Pilbara Seed Atlas and Field Guide: Plant Restoration in Australia's Arid Northwest. CSIRO Publishing, Dickson, Australia, pp. 7-16.

Fang, C., Radosevich, M., Fuhrmann, J.J., 2001. Atrazine and phenanthrene degradation in grass rhizosphere soil. Soil Biology and Biochemistry 33, 671-678.

Farley, G.J., Bellairs, S.M., Adkins, S.W., 2013. Germination of selected Australian native grass species, with potential for minesite rehabilitation. Australian Journal of Botany 61, 283-290.

Fenner, M., 1985. Seed Ecology Chapman and Hall. New York 145.

Ferro, A., Kennedy, J., Doucette, W., Nelson, S., Jauregui, G., McFarland, B., Bugbee, B., 1997. Fate of benzene in soils planted with alfalfa: uptake, volatilization, and degradation, in: Kruger, E.L., Anderson, T.A., Coats, J.R. (Eds.), Phytoremediation of Soil and Water Contaminants. American Chemical Society Symposium, Washington, D.C., 664, 223-237. 
Fletcher, J.S., Johnson, F.L., McFarlane, J.C., 1990. Influence of greenhouse versus field testing and taxonomic differences on plant sensitivity to chemical treatment. Environmental Toxicology and Chemistry 9, 769-776.

Frick, C., Germida, J., Farrell, R., 1999. Assessment of phytoremediation as an in-situ technique for cleaning oil-contaminated sites. Technical Report Petroleum Technology Alliance of Canada, Calgary. $105-124$. www.ag.usask.ca/departments/scsr/department/research/phytosurveys.pdf.

Frische, T., 2003. Ecotoxicological evaluation of in situ bioremediation of soils contaminated by the explosive 2, 4, 6-trinitrotoluene (TNT). Environmental Pollution 121, 103-113.

Fujikawa, K., Fort, F.L., Samejima, K., Sakamoto, Y., 1993. Genotoxic potency in Drosophila melanogaster of selected aromatic amines and polycyclic aromatic hydrocarbons as assayed in the DNA repair test. Mutation Research/Fundamental and Molecular Mechanisms of Mutagenesis 290, 175-182.

Gao, Y., Zhu, L., 2004. Plant uptake, accumulation and translocation of phenanthrene and pyrene in soils. Chemosphere 55, 1169-1178.

Gaskin, S., Soole, K., Bentham, R., 2008. Screening of Australian native grasses for rhizoremediation of aliphatic hydrocarbon-contaminated soil. International Journal of Phytoremediation 10, 378-389.

Gaskin, S.E., Bentham, R.H., 2010. Rhizoremediation of hydrocarbon contaminated soil using Australian native grasses. Science of the Total Environment 408, 3683-3688.

Gerhardt, K.E., Huang, X.-D., Glick, B.R., Greenberg, B.M., 2009. Phytoremediation and rhizoremediation of organic soil contaminants: Potential and challenges. Plant Science 176, 20-30.

Germida, J., Frick, C., Farrell, R., 2002. Phytoremediation of oil-contaminated soils. Developments in Soil Science 28, 169-186.

Ghanem, A., D’Orazio, V., Senesi, N., 2010. Phytotoxicity assay of selected plants to pyrene contaminated soils, in: Gilkes, R.J., Prakongkep, N. (Eds.), Proceedings of the 19th World Congress of Soil Science, Soil Solutions for a Changing World, Brisbane, Australia. ISN 978-0-646-53783-2. International Union of Soil Sciences, Published on DVD. pp. 74-77.

Gill, L., Nyawuame, H., Ehikhametalor, A., 1992. Effect of crude oil on the growth and anatomical features of Chromolaena odorata (L.) K. \& R. Chromolaena Odorata Newsletter 6, 1-6. http://www.arc.agric.za/arc-ppri/Newsletter\%20Library/C\%20odorata $\% 20$ No6\%20Oct1992.pdf

Giller, K.E., 2001. Nitrogen Fixation in Tropical Cropping Systems. CABI Publishing, Wallingford, UK and New York, USA.

Gilyazov, M., Gaisin, I., 2003. The agroecological characteristic and recultivation ways of the petropolluted chernozems of Tatarstan Republic. Phen Press, Kazan.

Graham, P., Vance, C., 2000. Nitrogen fixation in perspective: an overview of research and extension needs. Field Crops Research 65, 93-106.

Graj, W., Lisiecki, P., Szulc, A., Chrzanowski, Ł., Wojtera-Kwiczor, J., 2013. Bioaugmentation with petroleum-degrading consortia has a selective growth-promoting impact on crop plants germinated in diesel oil-contaminated soil. Water, Air, \& Soil Pollution 224, 1-15.

Gudin, C., Syratt, W., 1975. Biological aspects of land rehabilitation following hydrocarbon contamination. Environmental Pollution (1970) 8, 107-112.

Gunderson, C.A., Kostuk, J.M., Gibbs, M.H., Napolitano, G.E., Wicker, L.F., Richmond, J.E., Stewart, A.J., 1997. Multispecies toxicity assessment of compost produced in bioremediation of an explosives-contaminated sediment. Environmental Toxicology and Chemistry 16, 2529-2537. 
Günther, T., Dornberger, U., Fritsche, W., 1996. Effects of ryegrass on biodegradation of hydrocarbons in soil. Chemosphere 33, 203-215.

Haling, R.E., Yang, Z., Shadwell, N., Culvenor, R.A., Stefanski, A., Ryan, M.H., Sandral, G.A., Kidd, D.R., Lambers, H., Simpson, R.J., 2016. Growth and root dry matter allocation by pasture legumes and a grass with contrasting external critical phosphorus requirements. Plant and Soil, 407, 67-79.

Hall, J., Soole, K., Bentham, R., 2011. Hydrocarbon phytoremediation in the family Fabaceaa review. International Journal of Phytoremediation 13, 317-332.

Harper, J., 1939. The effect of natural gas on the growth of micro-organisms and the accumulation of nitrogen and organic matter in the soil. Soil Science 48, 461-466.

Harris, J.A., Birch, P., Palmer, J.P., 1996. Land Restoration and Reclamation: Principles and Practice. Addison Wesley Longman Ltd, Michigan.

Henner, P., Schiavon, M., Druelle, V., Lichtfouse, E., 1999. Phytotoxicity of ancient gaswork soils. Effect of polycyclic aromatic hydrocarbons (PAHs) on plant germination. Organic Geochemistry 30, 963-969.

Hernández-Ortega, H.A., Quintanar-Isaías, P.A., Jaramillo-Pérez, A.T., Alarcón, A., FerreraCerrato, R., Lazzarini-Lechuga, R., 2014. Diesel effects on root hydraulic conductivity and morphological changes of the vascular cylinder in Medicago sativa. Environmental and Experimental Botany 105, 1-9.

Hinsinger, P., Gobran, G.R., Gregory, P.J., Wenzel, W.W., 2005. Rhizosphere geometry and heterogeneity arising from root-mediated physical and chemical processes. New Phytologist 168, 293-303.

Hund, K., Traunspurger, W., 1994. Ecotox-evaluation strategy for soil bioremediation exemplified for a PAH-contaminated site. Chemosphere 29, 371-390.

Hutchinson, S., Schwab, A., Banks, M., 2003. Biodegradation of petroleum hydrocarbons in the rhizosphere, in: McCutcheon, S.C., Schnoor, J.L. (Eds.), Phytoremediation: Transformation and Control of Contaminants. Wiley-Interscience, New Jersey, pp. 355386.

Hutchinson, S.L., Banks, M., Schwab, A., 2001. Phytoremediation of aged petroleum sludge. Journal of Environmental Quality 30, 395-403.

ISO 11269-2, 2012. Soil quality - Determination of the effects of pollutants on soil flora - Part 2: Effects of contaminated soil on the emergence and early growth of higher plants.

Issoufi, I., Rhykerd, R., Smiciklas, K., 2006. Seedling growth of agronomic crops in crude oil contaminated soil. Journal of Agronomy and Crop Science 192, 310-317.

Jakobsen, I., Abbott, L., Robson, A., 1992. External hyphae of vesicular-arbuscular mycorrhizal fungi associated with Trifolium subterraneum L. New Phytologist 120, 371380 .

James, J.J., Sheley, R.L., Erickson, T., Rollins, K.S., Taylor, M.H., Dixon, K.W., 2013. A systems approach to restoring degraded drylands. Journal of Applied Ecology 50, 730739.

Joner, E., Corgie, S., Amellal, N., Leyval, C., 2002. Nutritional constraints to degradation of polycyclic aromatic hydrocarbons in a simulated rhizosphere. Soil Biology and Biochemistry 34, 859-864.

Joner, E.J., Leyval, C., 2001. Influence of arbuscular mycorrhiza on clover and ryegrass grown together in a soil spiked with polycyclic aromatic hydrocarbons. Mycorrhiza 10, 155-159.

Kamath, R., Rentz, J., Schnoor, J.L., Alvarez, P., 2004. Phytoremediation of hydrocarboncontaminated soils: principles and applications, in: Vazquez-Duhalt, R., QuinteroRamirez, R. (Eds), Petroleum Biotechnology: Developments and Perspectives 151, 447478. 
Kirk, J.L., Klirnomos, J.N., Lee, H., Trevors, J.T., 2002. Phytotoxicity assay to assess plant species for phytoremediation of petroleum-contaminated soil. Bioremediation Journal 6 , $57-63$.

Kirk, J.L., Klironomos, J.N., Lee, H., Trevors, J.T., 2005. The effects of perennial ryegrass and alfalfa on microbial abundance and diversity in petroleum contaminated soil. Environmental Pollution 133, 455-465.

Klassen, C., Eaton, D., 1991. Principles of Toxicity. Pergamon Press, New York.

Klokk, T., 1984. Effects of oil pollution on the germination and vegetative growth of five species of vascular plant. Oil and Petrochemical Pollution 2, 25-30.

Kolb, M., Harms, H., 2000. Metabolism of fluoranthene in different plant cell cultures and intact plants. Environmental Toxicology and Chemistry 19, 1304-1310.

Korade, D., Fulekar, M., 2009. Effect of organic contaminants on seed germination of Lolium multiflorum in soil. Biology and Medicine 1, 28-34.

KSU, 2012. Phytoremediation database. http://www.agronomy.kstate.edu/extension/environmental-quality/phytoremediation.html. Kansas State University.

Kuiper, I., Lagendijk, E.L., Bloemberg, G.V., Lugtenberg, B.J.J., 2004. Rhizoremediation: a beneficial plant-microbe interaction. Molecular plant-microbe interactions 17, 6-15.

Kulakow, P.A., Schwab, A., Banks, M., 2000. Screening plant species for growth on weathered, petroleum hydrocarbon-contaminated sediments. International Journal of Phytoremediation 2, 297-317.

Lamichhane, S., Krishna, K.B., Sarukkalige, R., 2016. Polycyclic aromatic hydrocarbons (PAHs) removal by sorption: A review. Chemosphere 148, 336-353.

Lee, S.-H., Lee, W.-S., Lee, C.-H., Kim, J.-G., 2008. Degradation of phenanthrene and pyrene in rhizosphere of grasses and legumes. Journal of Hazardous Materials 153, 892-898.

Leys, N.M., Bastiaens, L., Verstraete, W., Springael, D., 2005. Influence of the carbon/nitrogen/phosphorus ratio on polycyclic aromatic hydrocarbon degradation by Mycobacterium and Sphingomonas in soil. Applied Microbiology and Biotechnology 66, 726-736.

Licht, L.A., Isebrands, J., 2005. Linking phytoremediated pollutant removal to biomass economic opportunities. Biomass and Bioenergy 28, 203-218.

Liu, H., Weisman, D., Ye, Y.-b., Cui, B., Huang, Y.-h., Colón-Carmona, A., Wang, Z.-h., 2009. An oxidative stress response to polycyclic aromatic hydrocarbon exposure is rapid and complex in Arabidopsis thaliana. Plant Science 176, 375-382.

Louvel, B., Cébron, A., Leyval, C., 2011. Root exudates affect phenanthrene biodegradation, bacterial community and functional gene expression in sand microcosms. International Biodeterioration \& Biodegradation 65, 947-953.

Ma, B., He, Y., Chen, H.-h., Xu, J.-m., Rengel, Z., 2010. Dissipation of polycyclic aromatic hydrocarbons (PAHs) in the rhizosphere: synthesis through meta-analysis. Environmental Pollution 158, 855-861.

Macek, T., Mackova, M., Káš, J., 2000. Exploitation of plants for the removal of organics in environmental remediation. Biotechnology Advances 18, 23-34.

MacKinnon, G., Duncan, H.J., 2013. Phytotoxicity of branched cyclohexanes found in the volatile fraction of diesel fuel on germination of selected grass species. Chemosphere 90, 952-957.

Maddock, E., 2015. Diesel spill confirmed at controversial Port Melville in Tiwi Islands, ABC News Australia. http://www.abc.net.au/news/2015-05-15/diesel-spill-confirmed-atcontroversial-port-melville/6474230. Retrieved 30 March 2016. 
Maila, M.P., Cloete, T.E., 2002. Germination of Lepidium sativum as a method to evaluate polycyclic aromatic hydrocarbons (PAHs) removal from contaminated soil. International Biodeterioration \& Biodegradation 50, 107-113.

Maila, M.P., Cloete, T.E., 2005. The use of biological activities to monitor the removal of fuel contaminants-perspective for monitoring hydrocarbon contamination: a review. International Biodeterioration \& Biodegradation 55, 1-8.

Malallah, G., Afzal, M., Gulshan, S., Abraham, D., Kurian, M., Dhami, M., 1996. Vicia faba as a bioindicator of oil pollution. Environmental Pollution 92, 213-217.

Marques, M., Rosa, G., Aguiar, C., Correia, S., Carvalho, E., 2010. Seedling emergence and biomass growth of oleaginous and other tropical species in oil contaminated soil. Open Waste Management Journal 3, 26-32.

Marschner, H., 1995. Mineral Nutrition of Higher Plants. Academic Press Limited, London, UK.

Martin, B.C., George, S.J., Price, C.A., Ryan, M.H., Tibbett, M., 2014. The role of root exuded low molecular weight organic anions in facilitating petroleum hydrocarbon degradation: current knowledge and future directions. Science of the Total Environment 472, 642-653.

Martyn, A., Merritt, D., Turner, S., 2009. Seed banking, in: Offord, C.A., Meagher, P.F. (Eds.), Plant Germplasm Conservation in Australia: Strategies and Guidelines for Developing, Managing and Utilising ex situ Collections. Australian Network for Plant Conservation, Canberra, Australia, pp. 63-86.

McCready, S., Slee, D., Birch, G., Taylor, S., 2000. The distribution of polycyclic aromatic hydrocarbons in surficial sediments of Sydney Harbour, Australia. Marine Pollution Bulletin 40, 999-1006.

McGill, W., Rowell, M., 1977. The Reclamation of Agricultural Soils after Oil Spills. Dekker, New York.

Meador, J., Stein, J., Reichert, W., Varanasi, U., 1995. Bioaccumulation of polycyclic aromatic hydrocarbons by marine organisms, in: Ware, G.W. (Ed.), Reviews of Environmental Contamination and Toxicology. Springer-Verlag, New York, pp. 79-165.

Megharaj, M., Singleton, I., McClure, N., Naidu, R., 2000. Influence of petroleum hydrocarbon contamination on microalgae and microbial activities in a long-term contaminated soil. Archives of Environmental Contamination and Toxicology 38, 439-445.

Meier, J.R., Chang, L.W., Jacobs, S., Torsella, J., Meckes, M.C., Smith, M.K., 1997. Use of plant and earthworm bioassays to evaluate remediation of soil from a site contaminated with polychlorinated biphenyls. Environmental Toxicology and Chemistry 16, 928-938.

Meng, L., Qiao, M., Arp, H.P.H., 2011. Phytoremediation efficiency of a PAH-contaminated industrial soil using ryegrass, white clover, and celery as mono-and mixed cultures. Journal of Soils and Sediments 11, 482-490.

Merkl, N., Schultze-Kraft, R., Infante, C., 2005. Assessment of tropical grasses and legumes for phytoremediation of petroleum-contaminated soils. Water, Air, and Soil Pollution 165, 195-209.

Merritt, D., Turner, S., Clarke, S., Dixon, K., 2007. Seed dormancy and germination stimulation syndromes for Australian temperate species. Australian Journal of Botany 55, 336-344.

Merritt, D.J., Dixon, K.W., 2011. Restoration seed banks-a matter of scale. Science 332, 424425.

Mezzari, M.P., Zimermann, D.M.H., Corseuil, H.X., Nogueira, A.V., 2011. Potential of grasses and rhizosphere bacteria for bioremediation of diesel-contaminated soils. Revista Brasileira de Ciência do Solo 35, 2227-2236. 
Michael, R., Yuen, S., Baker, A., Laidlaw, W., Bateman, C., 2007. A sustainable approach for hydraulic control of landfills using quarry scalpings and native plants. Australian Journal of Multi-disciplinary Engineering 5, 39-47.

Miller, W., Peterson, S., Greene, J., Callahan, C., 1985. Comparative toxicology of laboratory organisms for assessing hazardous waste sites. Journal of Environmental Quality 14, 569574.

Mittler, R., Vanderauwera, S., Gollery, M., Van Breusegem, F., 2004. Reactive oxygen gene network of plants. Trends in Plant science 9, 490-498.

Miya, R.K., Firestone, M.K., 2001. Enhanced phenanthrene biodegradation in soil by slender oat root exudates and root debris. Journal of Environmental Quality 30, 1911-1918.

Murphy, H., 1929. Some effects of crude petroleum on nitrate production, seed germination and growth. Soil Science 27, 117-120.

Naidoo, G., Naidoo, Y., Achar, P., 2010. Responses of the mangroves Avicennia marina and Bruguiera gymnorrhiza to oil contamination. Flora-Morphology, Distribution, Functional Ecology of Plants 205, 357-362.

NDSU, 2012. Phytoremediation database. http://www.steviefamulari.net/phytoremediation/.

Nichols, T., Wolf, D., Rogers, H., Beyrouty, C., Reynolds, C., 1997. Rhizosphere microbial populations in contaminated soils. Water, Air, and Soil Pollution 95, 165-178.

Njoku, K.L., Akinola, M.O. and Oboh, B.O., 2008. Germination, survival and growth of accession of Glycine max L.(Merril)(soybean) and Lycopersicon esculentum L.(tomato) in crude oil polluted soil. Research Journal of Environmental Toxicology 2, 77-84.

Njoku, K.L., Akinola, M.O. and Oshodin, O.R., 2011. Phytotoxicity assay of crude oil using different accessions of Sorghum bicolor. World Applied Sciences Journal 15, 38-46.

Noori, A.S., Maivan, H.Z., Alaie, E., 2014. Leucanthemum vulgare Lam. germination, growth and mycorrhizal symbiosis under crude oil contamination. International Journal of Phytoremediation 16, 962-970.

O'Connor, P.J., Smith, S.E., Smith, F.A., 2001. Arbuscular mycorrhizal associations in the southern Simpson Desert. Australian Journal of Botany 49, 493-499.

Ogbo, E.M., 2009. Effects of diesel fuel contamination on seed germination of four crop plants-Arachis hypogaea, Vigna unguiculata, Sorghum bicolor and Zea mays. African Journal of Biotechnology 8, 250-253.

Olson, P.E., Castro, A., Joern, M., DuTeau, N.M., Pilon-Smits, E.A., Reardon, K.F., 2007a. Comparison of plant families in a greenhouse phytoremediation study on an aged polycyclic aromatic hydrocarbon-contaminated soil. Journal of Environmental Quality 36, 1461-1469.

Olson, P.E., Castro, A., Joern, M., DuTeau, N.M., Pilon-Smits, E.A.H., Reardon, K.F., 2007b. Comparison of plant families in a greenhouse phytoremediation study on an aged polycyclic aromatic hydrocarbon-contaminated soil. Journal of Environmental Quality 36, 1461-1469.

Olson, P.E., Fletcher, J.S., 2000. Ecological recovery of vegetation at a former industrial sludge basin and its implications to phytoremediation. Environmental Science and Pollution Research 7, 195-204.

Oyedeji, A., Adebiyi, A., Omotoyinbo, M., Ogunkunle, C., 2012. Effect of crude oilcontaminated soil on germination and growth performance of Abelmoschus esculentus L. Moench-A widely cultivated vegetable crop in Nigeria. American Journal of Plant Sciences 3, 1451-1454.

Palmerlee, A.P., Young, T.P., 2010. Direct seeding is more cost effective than container stock across ten woody species in California. Native Plants Journal 11, 89-102.

Palmroth, M.R., Pichtel, J., Puhakka, J.A., 2002. Phytoremediation of subarctic soil contaminated with diesel fuel. Bioresource technology 84, 221-228. 
Parrish, Z.D., Banks, M.K., Schwab, A.P., 2005. Effect of root death and decay on dissipation of polycyclic aromatic hydrocarbons in the rhizosphere of yellow sweet clover and tall fescue. Journal of Environmental Quality 34, 207-216.

Peng, S., Zhou, Q., Cai, Z., Zhang, Z., 2009. Phytoremediation of petroleum contaminated soils by Mirabilis jalapa L. in a greenhouse plot experiment. Journal of Hazardous Materials 168, 1490-1496.

Phillips, T., Liu, D., Seech, A., Lee, H., Trevors, J., 2000. Monitoring bioremediation in creosote-contaminated soils using chemical analysis and toxicity tests. Journal of Industrial Microbiology and Biotechnology 24, 132-139.

Pilon-Smits, E.A.H., 2005. Phytoremediation. Annual Review of Plant Biology 56, 15-39.

Plice, M., 1948. Some effects of crude petroleum on soil fertility, Proceedings of Soil Science Society of America, pp. 413-416.

Potashev, K., Sharonova, N., Breus, I., 2014. The use of cluster analysis for plant grouping by their tolerance to soil contamination with hydrocarbons at the germination stage. Science of the Total Environment 485, 71-82.

Reed, M.L., Glick, B.R., 2005. Growth of canola (Brassica napus) in the presence of plant growth-promoting bacteria and either copper or polycyclic aromatic hydrocarbons. Canadian Journal of Microbiology 51, 1061-1069.

Reilley, K., Banks, M., Schwab, A., 1996. Dissipation of polycyclic aromatic hydrocarbons in the rhizosphere. Journal of Environmental Quality 25, 212-219.

Ren, L., Zeiler, L.F., Dixon, D.G., Greenberg, B.M., 1996. Photoinduced effects of polycyclic aromatic hydrocarbons on Brassica napus (canola) during germination and early seedling development. Ecotoxicology and Environmental Safety 33, 73-80.

Rentz, J.A., Alvarez, P.J., Schnoor, J.L., 2005. Benzo [a] pyrene co-metabolism in the presence of plant root extracts and exudates: Implications for phytoremediation. Environmental Pollution 136, 477-484.

Reynoso-Cuevas, L., Gallegos-Martínez, M., Cruz-Sosa, F., Gutiérrez-Rojas, M., 2008. In vitro evaluation of germination and growth of five plant species on medium supplemented with hydrocarbons associated with contaminated soils. Bioresource Technology 99, 63796385.

Rezek, J., in der Wiesche, C., Mackova, M., Zadrazil, F., Macek, T., 2008. The effect of ryegrass (Lolium perenne) on decrease of PAH content in long term contaminated soil. Chemosphere 70, 1603-1608.

Robson, D.B., 2003. Phytoremediation of hydrocarbon-contaminated soil using plants adapted to western Canadian climate. PhD Thesis. University of Saskatchewan, Saskatoon.

Robson, D.B., Germida, J.J., Farrell, R.E., Knight, D.J., 2004a. Hydrocarbon tolerance correlates with seed mass and relative growth rate. Bioremediation Journal 8, 185-199.

Robson, D.B., Knight, J.D., Farrell, R.E., Germida, J.J., 2004b. Natural revegetation of hydrocarbon-contaminated soil in semi-arid grasslands. Canadian Journal of Botany 82, 22-30.

Rochman, C.M., Manzano, C., Hentschel, B.T., Simonich, S.L.M., Hoh, E., 2013. Polystyrene plastic: a source and sink for polycyclic aromatic hydrocarbons in the marine environment. Environmental Science \& Technology 47, 13976-13984.

Rowell, M., 1977. The effect of crude oil spills on soils in: Toogood, J.A. (Ed.), A Review of Literature. The Reclamation of Agricultural Soils after Oil Spills. University of Alberta, Edmonton. pp.1-33.

Ryan, P.R., James, R.A., Weligama, C., Delhaize, E., Rattey, A., Lewis, D.C., Bovill, W.D., McDonald, G., Rathjen, T.M., Wang, E., 2014. Can citrate efflux from roots improve phosphorus uptake by plants? Testing the hypothesis with near-isogenic lines of wheat. Physiologia Plantarum 151, 230-242. 
Salanitro, J.P., Dorn, P.B., Huesemann, M.H., Moore, K.O., Rhodes, I.A., Rice Jackson, L.M., Vipond, T.E., Western, M.M., Wisniewski, H.L., 1997. Crude oil hydrocarbon bioremediation and soil ecotoxicity assessment. Environmental Science \& Technology 31, 1769-1776.

Samanta, S.K., Singh, O.V., Jain, R.K., 2002. Polycyclic aromatic hydrocarbons: environmental pollution and bioremediation. Trends in Biotechnology 20, 243-248.

Sandermann Jr, H., 1994. Higher plant metabolism of xenobiotics: the 'green liver' concept. Pharmacogenetics 4, 225.

Saterbak, A., Toy, R.J., Wong, D.C., McMain, B.J., Williams, M.P., Dorn, P.B., Brzuzy, L.P., Chai, E.Y., Salanitro, J.P., 1999. Ecotoxicological and analytical assessment of hydrocarbon-contaminated soils and application to ecological risk assessment. Environmental Toxicology and Chemistry 18, 1591-1607.

Sayles, G.D., Acheson, C.M., Kupferle, M.J., Shan, Y., Zhou, Q., Meier, J.R., Chang, L., Brenner, R.C., 1999. Land treatment of PAH-contaminated soil: performance measured by chemical and toxicity assays. Environmental Science \& Technology 33, 4310-4317.

Scheunert, I., Topp, E., Attar, A., Korte, F., 1994. Uptake pathways of chlorobenzenes in plants and their correlation with n-octanol/water partition coefficients. Ecotoxicology and Environmental Safety 27, 90-104.

Schnoor, J.L., Light, L.A., McCutcheon, S.C., Wolfe, N.L., Carreia, L.H., 1995. Phytoremediation of organic and nutrient contaminants. Environmental Science \& Technology 29, 318A-323A.

Serrano, A., Tejada, M., Gallego, M., Gonzalez, J.L., 2009. Evaluation of soil biological activity after a diesel fuel spill. Science of the Total Environment 407, 4056-4061.

Shahsavari, E., Adetutu, E.M., Anderson, P.A., Ball, A.S., 2013. Tolerance of selected plant species to petrogenic hydrocarbons and effect of plant rhizosphere on the microbial removal of hydrocarbons in contaminated soil. Water, Air, \& Soil Pollution 224, 1-14.

Sharifi, M., Sadeghi, Y., Akbarpour, M., 2007. Germination and growth of six plant species on contaminated soil with spent oil. International Journal of Environmental Science \& Technology 4, 463-470.

Sharonova, N., Breus, I., 2012. Tolerance of cultivated and wild plants of different taxonomy to soil contamination by kerosene. Science of the Total Environment 424, 121-129.

Shimp, J., Tracy, J., Davis, L., Lee, E., Huang, W., Erickson, L., Schnoor, J., 1993. Beneficial effects of plants in the remediation of soil and groundwater contaminated with organic materials. Critical Reviews in Environmental Science and Technology 23, 41-77.

Siciliano, S., Germida, J., 1998. Mechanisms of phytoremediation: biochemical and ecological interactions between plants and bacteria. Environmental Reviews 6, 65-79.

Siciliano, S.D., Germida, J.J., Headley, J.V., 1997. Evaluation of prairie grass species as bioindicators of halogenated aromatics in soil. Environmental Toxicology and Chemistry $16,521-527$.

Siddiqui, S., Adams, W.A., 2002. The fate of diesel hydrocarbons in soils and their effect on the germination of perennial ryegrass. Environmental Toxicology 17, 49-62.

Simonich, S.L., Hites, R.A., 1995. Organic pollutant accumulation in vegetation. Environmental Science \& Technology 29, 2905-2914.

Singer, A.C., Crowley, D.E., Thompson, I.P., 2003. Secondary plant metabolites in phytoremediation and biotransformation. Trends in Biotechnology 21, 123-130.

Smith, M., Flowers, T., Duncan, H., Alder, J., 2006. Effects of polycyclic aromatic hydrocarbons on germination and subsequent growth of grasses and legumes in freshly contaminated soil and soil with aged PAHs residues. Environmental Pollution 141, 519525 . 
Smreczak, B., Kordybach, B.M., 2003. Seeds germination and root growth of selected plants in PAH contaminated soil. Fresenius Environmental Bulletin 12, 946-949.

Stroud, J., Paton, G., Semple, K.T., 2007. Microbe-aliphatic hydrocarbon interactions in soil: implications for biodegradation and bioremediation. Journal of Applied Microbiology 102, $1239-1253$.

Suriyagoda, L.D., Lambers, H., Renton, M., Ryan, M.H., 2012. Growth, carboxylate exudates and nutrient dynamics in three herbaceous perennial plant species under low, moderate and high phosphorus supply. Plant and Soil 358, 105-117.

Susarla, S., Medina, V.F., McCutcheon, S.C., 2002. Phytoremediation: an ecological solution to organic chemical contamination. Ecological Engineering 18, 647-658.

Sverdrup, L.E., Hagen, S.B., Krogh, P.H., van Gestel, C.A., 2007. Benzo (a) pyrene shows low toxicity to three species of terrestrial plants, two soil invertebrates, and soil-nitrifying bacteria. Ecotoxicology and Environmental Safety 66, 362-368.

Taiz, L., Zeiger, E., Møller, I.M., Murphy, A., 2015. Plant Physiology and Development. $6^{\text {th }}$ Edition. Sinauer Associates, Incorporated.

Tang, J., Liste, H.-H., Alexander, M., 2002. Chemical assays of availability to earthworms of polycyclic aromatic hydrocarbons in soil. Chemosphere 48, 35-42.

Tao, Y., Zhang, S., Wang, Z., Christie, P., 2009. Predicting bioavailability of PAHs in fieldcontaminated soils by passive sampling with triolein embedded cellulose acetate membranes. Environmental Pollution 157, 545-551.

Thomas, J., Skalski, J., Cline, J., McShane, M., Simpson, J., Miller, W., Peterson, S., Callahan, C., Greene, J., 1986. Characterization of chemical waste site contamination and determination of its extent using bioassays. Environmental Toxicology and Chemistry 5, 487-501.

Tibbett, M., George, S.J., Davie, A., Barron, A., Milton, N., Greenwood, P.F., 2011. Just add water and salt: the optimisation of petrogenic hydrocarbon biodegradation in soils from semi-arid Barrow Island, Western Australia. Water, Air, \& Soil Pollution 216, 513-525.

Trapp, S., Köhler, A., Larsen, L.C., Zambrano, K.C., Karlson, U., 2001. Phytotoxicity of fresh and weathered diesel and gasoline to willow and poplar trees. Journal of Soils and Sediments 1, 71-76.

Udo, E., Fayemi, A., 1975. The effect of oil pollution of soil on germination, growth and nutrient uptake of corn. Journal of Environmental Quality 4, 537-540.

USEPA, 2000. Introduction to Phytoremediation. EPA 600-R-99-107, Office of Research and Development. http://clu-in.org/download/remed/introphyto.pdf

USEPA, Clu-in. Contaminated Site Clean-up Information (Clu-in). Available from: http://www.clu-in.org/. Retrieved 30 March 2016.

Vwioko, D., Fashemi, D., 2005. Growth response of Ricinus communis L. (castor oil) in spent lubricating oil polluted soil. Journal of Applied Sciences and Environmental Management 9, 73-79.

Walworth, J., Reynolds, C., 1995. Bioremediation of a petroleum-contaminated cryic soil: Effects of phosphorus, nitrogen, and temperature. Soil and Sediment Contamination 4, 299-310.

Walworth, J., Woolard, C., Braddock, J., Reynolds, C., 1997. Enhancement and inhibition of soil petroleum biodegradation through the use of fertilizer nitrogen: an approach to determining optimum levels. Soil and Sediment Contamination 6, 465-480.

Wang, W., 1993. Comparative rice seed toxicity tests using filter paper, growth Pouch-TM, and seed tray methods. Environmental Monitoring and Assessment 24, 257-265.

Wang, W., Freemark, K., 1995. The use of plants for environmental monitoring and assessment. Ecotoxicology and Environmental Safety 30, 289-301. 
Wang, X., Sun, C., Gao, S., Wang, L., Shuokui, H., 2001. Validation of germination rate and root elongation as indicator to assess phytotoxicity with Cucumis sativus. Chemosphere 44, 1711-1721.

Wang, X., Wang, Y., Chunsheng, Y., Wang, L., Han, S., 2002. Mechanism-based quantitative structure-phytotoxicity relationships comparative inhibition of substituted phenols on root elongation of Cucumis sativus. Archives of Environmental contamination and Toxicology 42, 29-35.

Wang, Z., Liu, Z., Yang, Y., Li, T., Liu, M., 2012. Distribution of PAHs in tissues of wetland plants and the surrounding sediments in the Chongming wetland, Shanghai, China. Chemosphere 89, 221-227.

Watkins, J., Sorensen, D., Sims, R., 1994. Volatilization and mineralization of naphthalene in soil-grass microcosms. In: Anderson T.A., Coats J.R. (eds.) Bioremediation through rhizosphere technology. American Chemical Society, Washington D.C. ACS Symposium Series 563, 123-131.

Wenzel, W.W., 2009. Rhizosphere processes and management in plant-assisted bioremediation (phytoremediation) of soils. Plant and Soil 321, 385-408.

Wierzbicka, M., Obidzińska, J., 1998. The effect of lead on seed imbibition and germination in different plant species. Plant Science 137, 155-171.

Wink, M., 1988. Plant breeding: importance of plant secondary metabolites for protection against pathogens and herbivores. Theoretical and Applied Genetics 75, 225-233.

Yang, Z., Culvenor, R., Haling, R., Stefanski, A., Ryan, M., Sandral, G., Kidd, D., Lambers, H., Simpson, R., 2015. Variation in root traits associated with nutrient foraging among temperate pasture legumes and grasses. Grass and Forage Science 72, 93-103..

Yateem, A., Al-Sharrah, T., Bin-Haji, A., 2007. Investigation of microbes in the rhizosphere of selected grasses for rhizoremediation of hydrocarbon-contaminated soils. Soil and Sediment Contamination: An International Journal 16, 269-280.

Zhou, W., Wang, X., Chen, C., Zhu, L., 2013. Enhanced soil washing of phenanthrene by a plant-derived natural biosurfactant, Sapindus saponin. Colloids and Surfaces A: Physicochemical and Engineering Aspects 425, 122-128.

Zhou, W., Yang, J., Lou, L., Zhu, L., 2011. Solubilization properties of polycyclic aromatic hydrocarbons by saponin, a plant-derived biosurfactant. Environmental Pollution 159, $1198-1204$. 
Table 3 Summary of experimental studies of seed germination and emergence under petrogenic contamination. (F-freshly spiked, A-aged contamination; concentration values in \% unless otherwise stated)

\begin{tabular}{|c|c|c|c|c|c|c|c|c|c|c|}
\hline Study & Contaminant & $\begin{array}{l}\text { Concentra } \\
\text { tion }\end{array}$ & $\begin{array}{l}\text { Growing } \\
\text { medium }\end{array}$ & Container & Days & $\begin{array}{l}\begin{array}{l}\text { No. of } \\
\text { species }\end{array} \\
\end{array}$ & Rep. & Seeds/rep. & Temperature & Parameters \\
\hline $\begin{array}{l}\text { Achuba } \\
2006\end{array}$ & crude oil $(\mathrm{F})$ & $\begin{array}{l}0.25,0.5,1, \\
2\end{array}$ & sandy soil & plastic bag & 12 & 1 & 20 & 5 & - & $\begin{array}{l}\text { germ. \%; amylase and phosphorylase activity; } \\
\text { sugar, amino acids, proteins and chlorophyll } \\
\text { content; root meristematic mitotic activity }\end{array}$ \\
\hline $\begin{array}{l}\text { Adam and } \\
\text { Duncan }\end{array}$ & a.diesel $(\mathrm{F})$ & $2.5,5$ & $\begin{array}{l}\text { sandy soil } \\
\text { (compost) }\end{array}$ & petri dish & 14 & 25 & 2 & 25 or 100 & $22^{\circ} \mathrm{C}$ & germ. $\%$ \\
\hline 2002 & b. diesel (F) & $2.5,5$ & as above & petri dish & 42 & 8 & 2 & 25 or 100 & $8^{\circ} \mathrm{C}$ & as above \\
\hline & c. diesel (A) & $2.5,5$ & as above & petri dish & 14 & 5 & 2 & 25 or 100 & $22^{\circ} \mathrm{C}$ & as above \\
\hline & $\begin{array}{l}\text { d. seeds soaked } \\
\text { in diesel for } 7 \\
\text { d }\end{array}$ & & as above & petri dish & 14 & 1 & 2 & 40 & $22^{\circ} \mathrm{C}$ & as above, tetrazolium test for seed viability \\
\hline $\begin{array}{l}\text { Adenipekun } \\
\text { et al. } 2008\end{array}$ & spent oil $(\mathrm{F})$ & $\begin{array}{l}0.2,0.4 \\
0.6,0.8,1 \\
2,3\end{array}$ & top soil & $\begin{array}{l}\text { black } \\
\text { polythene } \\
\text { bag }\end{array}$ & 7 & 1 & 3 & - & $20 / 34^{\circ} \mathrm{C}$ & $\begin{array}{l}\text { plant height, stem girth, leaf number, area } \\
\text { and chlorophyll content, biomass, plant } \\
\text { moisture content }\end{array}$ \\
\hline $\begin{array}{l}\text { Amakiri } \\
\text { and } \\
\text { Onofeghara } \\
1984\end{array}$ & crude oil $(\mathrm{F})$ & $\begin{array}{l}\text { Seeds } \\
\text { soaked in } \\
\text { oil for } \\
\text { variable } \\
\text { periods }\end{array}$ & $\begin{array}{l}\text { filter } \\
\text { paper }\end{array}$ & petri dish & variable & 3 & 4 & 25 & $27^{\circ} \mathrm{C}$ & $\begin{array}{l}\text { germ. rate, germ. \%, tetrazolium test for } \\
\text { seed viability }\end{array}$ \\
\hline $\begin{array}{l}\text { Besalatpour } \\
\text { et al. } 2013\end{array}$ & $\begin{array}{l}\text { PAHs in } \\
\text { landfill soil } \\
\text { (A) }\end{array}$ & 4,7 & soil & plastic pot & 14 & 7 & 3 & - & $22^{\circ} \mathrm{C}$ or $37^{\circ} \mathrm{C}$ & $\begin{array}{l}\text { germ. \% and rate; shoot length, total } \\
\text { biomass }\end{array}$ \\
\hline $\begin{array}{l}\text { Bona et al. } \\
2011\end{array}$ & $\operatorname{diesel}(\mathrm{F})$ & $\begin{array}{l}9 \\
\text { (treatments } \\
\text { made by } \\
\text { timed } \\
\text { ageing) }\end{array}$ & soil & plastic tray & 20 & 1 & 5 & 50 & $38 / 9^{\circ} \mathrm{C}$ & $\begin{array}{l}\text { germ. \%, total height, fresh and dry } \\
\text { biomass, ecophyll biomass and leaf area }\end{array}$ \\
\hline $\begin{array}{l}\text { Bossert and } \\
\text { Bartha } \\
1985\end{array}$ & oily sludge & 8.4 & $\begin{array}{l}\text { sandy } \\
\text { loam }\end{array}$ & $\begin{array}{l}\text { polypropylen } \\
\text { e trays }\end{array}$ & 11 & 2 & 1 & 100 & ambient & $\begin{array}{l}\text { emergence, after } 25 \mathrm{~d} \text { - shoot height and dry } \\
\text { weight }\end{array}$ \\
\hline \multirow[t]{2}{*}{$\begin{array}{l}\text { Chaineau et } \\
\text { al. } 1997\end{array}$} & $\begin{array}{l}\text { a. fuel oil and } \\
\text { dearomatised } \\
\text { fuel oil }(\mathrm{F})\end{array}$ & $\begin{array}{l}\text { various, } 0.1 \\
\text { to } 20\end{array}$ & sand & $\begin{array}{l}\text { glass petri } \\
\text { dish }\end{array}$ & 8 & 7 & - & 100 & $22^{\circ} \mathrm{C}$ & germ. rate \\
\hline & $\begin{array}{l}\text { b. fuel oil; } \\
\text { light and heavy } \\
\text { fraction }(F)\end{array}$ & $\begin{array}{l}1,2,4,6,8 \\
10\end{array}$ & sand & $\begin{array}{l}\text { glass petri } \\
\text { dish }\end{array}$ & 8 & 1 & - & 100 & $22^{\circ} \mathrm{C}$ & as above \\
\hline
\end{tabular}




\begin{tabular}{|c|c|c|c|c|c|c|c|c|c|c|}
\hline Study & Contaminant & $\begin{array}{l}\text { Concentra } \\
\text { tion }\end{array}$ & $\begin{array}{l}\text { Growing } \\
\text { medium }\end{array}$ & Container & Days & $\begin{array}{l}\text { No. of } \\
\text { species }\end{array}$ & Rep. & Seeds/rep. & Temperature & Parameters \\
\hline $\begin{array}{l}\text { Chen et al. } \\
2013\end{array}$ & diesel $(F)$ & $\begin{array}{l}0.2,0.4 \\
0.8,1\end{array}$ & sand & petri dish & 30 & 1 & 3 & 30 & $28^{\circ} \mathrm{C}$ & $\begin{array}{l}\text { germ. } \% \text { and rate; root length, diameter and } \\
\text { surface area; shoot } \mathrm{H}_{2} \mathrm{O}_{2} \text { accumulation; } \\
\text { biomass DNA damage }\end{array}$ \\
\hline $\begin{array}{l}\text { Dorn and } \\
\text { Salanitro } \\
2000\end{array}$ & $\begin{array}{l}\text { a. light crude } \\
\text { oil (F) } \\
\text { b. medium } \\
\text { crude oil (F) } \\
\text { c. heavy crude } \\
\text { oil (F) } \\
\text { d. Two soils } \\
\text { (A) }\end{array}$ & 5 & $\begin{array}{l}\text { a. low } \\
\text { organic } \\
\text { carbon } \\
\text { soil } \\
\text { b. high } \\
\text { organic } \\
\text { carbon } \\
\text { soil }\end{array}$ & petri dish & 21 & 3 & - & 100 & - & $\begin{array}{l}\text { germ. } \% \text {, average dry weight per plant } \\
\text { as above }\end{array}$ \\
\hline $\begin{array}{l}\text { Gaskin et } \\
\text { al. } 2008\end{array}$ & $\begin{array}{l}\text { diesel-engine } \\
\text { oil mix (60:40) } \\
\text { (F) }\end{array}$ & $0.5,1$ & $\begin{array}{l}\text { mine site } \\
\text { soil }\end{array}$ & pots & 60 & 9 & 4 & 50 & $20-30^{\circ} \mathrm{C}$ & seedling emergence $\%$ \\
\hline $\begin{array}{l}\text { Ghanem et } \\
\text { al. } 2010\end{array}$ & pyrene $(F)$ & $\begin{array}{l}50,100 \\
\left(\mathrm{mg} \mathrm{kg}^{-1}\right)\end{array}$ & soil & $\begin{array}{l}\text { plastic petri } \\
\text { dish }\end{array}$ & 14 & 3 & 4 & 7 & ambient & germ. $\%$, shoot and root length \\
\hline $\begin{array}{l}\text { Graj et al. } \\
2013\end{array}$ & diesel $(\mathrm{F})$ & $\begin{array}{l}0.15,0.3 \\
0.6,1.2,2.4\end{array}$ & $\begin{array}{l}\text { soil, filter } \\
\text { paper on } \\
\text { top }\end{array}$ & Phytotoxkit & 6 & 4 & 3 & - & $22^{\circ} \mathrm{C}$ & $\begin{array}{l}\text { germ. rate, root length, dry biomass plus } \\
\text { bioaugmentation treatments }\end{array}$ \\
\hline \multirow[t]{4}{*}{$\begin{array}{l}\text { Henner et } \\
\text { al. } 1999\end{array}$} & $\begin{array}{l}\text { a. six pure } \\
\text { PAHs }\end{array}$ & $\begin{array}{l}20\left(\mathrm{mg} \mathrm{kg}^{-}\right. \\
\left.{ }_{1}\right)\end{array}$ & $\begin{array}{l}\text { soil; filter } \\
\text { paper }\end{array}$ & $\begin{array}{l}\text { glass petri } \\
\text { dish }\end{array}$ & 10 & $\begin{array}{l}1 \text { (soil); } \\
8\end{array}$ & 3 & $75-200$ & $21^{\circ} \mathrm{C}$ dark & germ. $\%$, after $60 \mathrm{~d}-$ height \\
\hline & $\begin{array}{l}\text { b. leachate of } \\
\text { contaminated }\end{array}$ & , & $\begin{array}{l}\text { filter } \\
\text { paper }\end{array}$ & $\begin{array}{l}\text { glass petri } \\
\text { dish }\end{array}$ & 10 & - & 3 & $75-200$ & $21^{\circ} \mathrm{C}$ dark & as above \\
\hline & $\begin{array}{l}\text { soil } \\
\text { c. viscous tar }\end{array}$ & $\begin{array}{l}14,30,50 \\
75,150 \\
\left(\mathrm{mg} \mathrm{kg}^{-1}\right)\end{array}$ & $\begin{array}{l}\text { agricultur } \\
\text { al soil }\end{array}$ & $\begin{array}{l}\text { glass petri } \\
\text { dish } \\
\text { (open/closed) }\end{array}$ & 10 & 2 & 3 & $75-200$ & $21^{\circ} \mathrm{C}$ dark & as above \\
\hline & $\begin{array}{l}\text { d. industrial } \\
\text { soil }(\mathrm{F} \text { and } \mathrm{A})\end{array}$ & $\begin{array}{l}3250(\mathrm{mg} \\
\left.\mathrm{kg}^{-1}\right)\end{array}$ & $\begin{array}{l}\text { industrial } \\
\text { soil }\end{array}$ & $\begin{array}{l}\text { glass petri } \\
\text { dish }\end{array}$ & 10 & 17 & - & $75-200$ & $21^{\circ} \mathrm{C}$ dark & as above \\
\hline $\begin{array}{l}\text { Issoufi et } \\
\text { al. } 2006\end{array}$ & $\begin{array}{l}\text { crude oil }(\mathrm{F}) \text {; } \\
\text { artificially } \\
\text { weathered by } \\
\text { heating }\end{array}$ & $1,5,10$ & silt loam & $\begin{array}{l}\text { conical cells } \\
\text { with } \\
\text { perforated } \\
\text { base, } \\
\text { suspended in } \\
\text { a container } \\
\end{array}$ & 28 & 6 & 5 & 5 & $24 / 18^{\circ} \mathrm{C}$ & $\begin{array}{l}\text { emergence } \% \text {, seedling height, shoot and } \\
\text { root dry weight }\end{array}$ \\
\hline $\begin{array}{l}\text { Korade and } \\
\text { Fulekar } \\
2009\end{array}$ & anthracene $(\mathrm{F})$ & $\begin{array}{l}10,25,50 \\
75,100 \\
\left(\mathrm{mg} \mathrm{kg}^{-1}\right)\end{array}$ & soil & petri dish & 7 & 1 & 3 & 10 & $26 / 23^{\circ} \mathrm{C}$ & germ. $\%$ \\
\hline $\begin{array}{l}\text { Kulakow et } \\
\text { al. } 2000\end{array}$ & $\begin{array}{l}\text { Contaminated } \\
\text { sediments (A) }\end{array}$ & na & $\begin{array}{l}\text { air-dried } \\
\text { sediments }\end{array}$ & pots & 14 & 29 & 4 & $50-100$ & $10 / 28^{\circ} \mathrm{C}$ & $\begin{array}{l}\text { seedling emergence; after } 60 \mathrm{~d} \text { - height, } \\
\text { aboveground biomass, root biomass, }\end{array}$ \\
\hline
\end{tabular}




\begin{tabular}{|c|c|c|c|c|c|c|c|c|c|c|}
\hline Study & Contaminant & $\begin{array}{l}\text { Concentra } \\
\text { tion }\end{array}$ & $\begin{array}{l}\text { Growing } \\
\text { medium }\end{array}$ & Container & Days & $\begin{array}{l}\text { No. of } \\
\text { species }\end{array}$ & Rep. & Seeds/rep. & Temperature & Parameters \\
\hline & & & & & & & & & & $\begin{array}{l}\text { root/shoot ratio, mean root diameter, root } \\
\text { length density, and root-surface-area density }\end{array}$ \\
\hline $\begin{array}{l}\text { MacKinnon } \\
\text { and Duncan }\end{array}$ & a. $\operatorname{diesel}(\mathrm{F})$ & $2.5,5$ & $\begin{array}{l}\text { sandy soil } \\
\text { (compost) }\end{array}$ & petri dish & 14 & 3 & 2 & 25 & $22^{\circ} \mathrm{C}$ & germ. $\%$ \\
\hline 2013 & $\begin{array}{l}\text { b. } 4 \\
\text { cycloalkanes } \\
\text { (F) }\end{array}$ & $\begin{array}{l}0.1,1,5 \\
\left(\mathrm{mg} \mathrm{L}^{-1}\right)\end{array}$ & $\begin{array}{l}\text { filter } \\
\text { paper }\end{array}$ & petri dish & 14 & 2 & 3 & 15 & $22^{\circ} \mathrm{C}$ & germ. $\%$, shoot length \\
\hline \multirow[t]{4}{*}{$\begin{array}{l}\text { Maila and } \\
\text { Cloete } 2002\end{array}$} & $\begin{array}{l}\text { a. } 5 \text { pure } \\
\text { compounds }(\mathrm{F})\end{array}$ & $\begin{array}{l}50,150, \\
300,500, \\
1000(\mathrm{mg} \\
\left.\mathrm{kg}^{-1}\right)\end{array}$ & $\begin{array}{l}\text { a. sandy } \\
\text { loam }\end{array}$ & $\begin{array}{l}\text { trays; } \\
\text { polystyrene } \\
\text { petri dish }\end{array}$ & 3 & 1 & 3 & 50 & ambient & germ. $\%$, seedling weight \\
\hline & $\begin{array}{l}\text { b. industrial } \\
\text { soil (A) }\end{array}$ & $\begin{array}{l}1.2\left(\mathrm{mg} \mathrm{kg}^{-}\right. \\
\left.{ }^{1}\right)\end{array}$ & $\begin{array}{l}\text { b. PHC } \\
\text { industrial } \\
\text { soil }\end{array}$ & $\begin{array}{l}\text { polystyrene } \\
\text { petri dish }\end{array}$ & 3 & 1 & 3 & 50 & ambient & as above \\
\hline & & control & $\begin{array}{l}\text { c. non } \\
\text { PHC } \\
\text { industrial } \\
\text { soil }\end{array}$ & $\begin{array}{l}\text { polystyrene } \\
\text { petri dish }\end{array}$ & 3 & 1 & 3 & 50 & ambient & as above \\
\hline & & control & $\begin{array}{l}\text { d.white } \\
\text { playpen } \\
\text { sand }\end{array}$ & $\begin{array}{l}\text { polystyrene } \\
\text { petri dish }\end{array}$ & 3 & 1 & 3 & 50 & ambient & as above \\
\hline $\begin{array}{l}\text { Marques et } \\
\text { al. } 2010\end{array}$ & $\begin{array}{l}\text { light crude oil } \\
\text { (F) }\end{array}$ & $\begin{array}{l}0.05,0.5,2 \\
4,6\end{array}$ & $\begin{array}{l}\text { sterilised } \\
\text { fine sand }\end{array}$ & HDPE box & 35 & 6 & 4 & 200 & $25^{\circ} \mathrm{C}$ & $\begin{array}{l}\text { germ. } \% \text {, germ. rate, germ. period, shoot and } \\
\text { root biomass }\end{array}$ \\
\hline $\begin{array}{l}\text { Mezzari et } \\
\text { al. } 2011\end{array}$ & diesel $(F)$ & $0.5,1,2$ & soil & plastic pot & 21 & 3 & 3 & - & - & $\begin{array}{l}\text { germ. \%, subsequent growth, biomass, soil } \\
\text { bacteria quantification }\end{array}$ \\
\hline $\begin{array}{l}\text { Murphy } \\
1929\end{array}$ & crude oil $(\mathrm{F})$ & $\begin{array}{l}\sim 7.5,2.5 \\
1.25,0.25\end{array}$ & soil & $\begin{array}{l}\text { Tin container } \\
\text { buried in } \\
\text { ground }\end{array}$ & 40 & 1 & 2 & 25 & - & germ. $\%$ \\
\hline $\begin{array}{l}\text { Noori et al. } \\
2014\end{array}$ & crude oil (F) & $\begin{array}{l}2.5,5,7.5 \\
10\end{array}$ & $\begin{array}{l}\text { sandy } \\
\text { loam } \\
\text { compost } \\
\text { (+/- } \\
\text { inoculum) }\end{array}$ & plastic pot & 112 & 1 & 3 & 5 & $30 / 5^{\circ} \mathrm{C}$ & $\begin{array}{l}\text { root and shoot length, dry weight, root to } \\
\text { shoot ratio, mycorrhizal colonization } \%, \\
\text { spore abundance per g soil }\end{array}$ \\
\hline Ogbo 2009 & diesel $(F)$ & $1,2,3,4,5$ & $\begin{array}{l}\text { filter } \\
\text { paper }\end{array}$ & petri dish & 3 & 4 & 5 & 10 & - & germ. $\%$, radicle and plumule length \\
\hline $\begin{array}{l}\text { Oyedeji et } \\
\text { al. } 2012\end{array}$ & crude oil $(\mathrm{F})$ & $\begin{array}{l}0.5,1,1.5 \\
2\left(\mathrm{ml} \mathrm{kg}^{-1}\right)\end{array}$ & loamy soil & planting bag & 21 & 1 & 5 & 3 & - & $\begin{array}{l}\text { emerg. \%, co-efficient of germination } \\
\text { velocity, seedling height and girth }\end{array}$ \\
\hline $\begin{array}{l}\text { Ren et al. } \\
1996\end{array}$ & $\begin{array}{l}\text { a. anthracene } \\
\text { b. } \\
\text { benzo }[\alpha] \text { pyren } \\
\text { e }\end{array}$ & $\begin{array}{l}\text { various, } 0- \\
10\left(\mathrm{mg} \mathrm{L}^{-1}\right)\end{array}$ & $\begin{array}{l}30 \mathrm{ml} \\
\text { dimethyl } \\
\text { sulfoxide }\end{array}$ & $\begin{array}{l}\text { seed tray of a } \\
\text { large } \\
\text { polystyrene } \\
\text { petri dish }\end{array}$ & 6 & 1 & 9 & 12 & - & Root and shoot growth, chlorosis \\
\hline
\end{tabular}




\begin{tabular}{|c|c|c|c|c|c|c|c|c|c|c|}
\hline Study & Contaminant & $\begin{array}{l}\text { Concentra } \\
\text { tion }\end{array}$ & $\begin{array}{l}\text { Growing } \\
\text { medium }\end{array}$ & Container & Days & $\begin{array}{l}\text { No. of } \\
\text { species }\end{array}$ & Rep. & Seeds/rep. & Temperature & Parameters \\
\hline & c. fluoranthene & & $\begin{array}{l}\text { test } \\
\text { solution }\end{array}$ & & & & & & & \\
\hline $\begin{array}{l}\text { Saterbak et } \\
\text { al. } 1999\end{array}$ & $\begin{array}{l}\text { a. crude oil (A) } \\
-7 \text { sites } \\
\text { b. lubricating } \\
\text { oil (A) }-1 \text { site }\end{array}$ & $\begin{array}{l}2-7 \\
\text { dilutions of } \\
\text { contaminat } \\
\text { ed soils }\end{array}$ & soil & $\begin{array}{l}\text { plastic petri } \\
\text { dish }\end{array}$ & 4 & 4 & 3 & 10 & $23^{\circ} \mathrm{C}$ dark & germ. $\%$, root length \\
\hline \multirow[t]{2}{*}{$\begin{array}{l}\text { Shahsavari } \\
\text { et al. } 2013\end{array}$} & $\begin{array}{l}\text { a. diesel- } \\
\text { engine oil }(\mathrm{F})\end{array}$ & 1 & sandy soil & plastic pot & 28 & 11 & 3 & $5-25$ & $27-30^{\circ} \mathrm{C}$ & $\begin{array}{l}\text { germ. } \% \text {, shoot and root length and dry } \\
\text { biomass }\end{array}$ \\
\hline & b. crude oil $(\mathrm{F})$ & 1 & sandy soil & plastic pot & 28 & 11 & 3 & $5-25$ & $27-30^{\circ} \mathrm{C}$ & as above \\
\hline $\begin{array}{l}\text { Sharifi et } \\
\text { al. } 2007\end{array}$ & engine oil $(\mathrm{F})$ & $\begin{array}{l}2.5,5,7.5 \\
10\end{array}$ & $\begin{array}{l}\text { artificial } \\
\text { sandy } \\
\text { loam }\end{array}$ & plastic pot & 14 & 6 & 3 & 20 & $27-30^{\circ} \mathrm{C}$ & germ. $\%$, shoot length and dry biomass \\
\hline $\begin{array}{l}\text { Sharonova } \\
\text { and Breus } \\
2012\end{array}$ & kerosene $(\mathrm{F})$ & $\begin{array}{l}1,2,3,5 \\
10,15\end{array}$ & $\begin{array}{l}\text { leached } \\
\text { chernoze } \\
\text { m soil }\end{array}$ & petri dish & 14 & 50 & - & $10-25$ & $26^{\circ} \mathrm{C}$ dark & germ. $\%$ \\
\hline \multirow[t]{3}{*}{$\begin{array}{l}\text { Siddiqui } \\
\text { and Adams } \\
2002\end{array}$} & $\begin{array}{l}\text { diesel (F) (agec } \\
24 \text { weekly }\end{array}$ & $\begin{array}{l}0.64,1.6,4, \\
\text { if, } 13.6\end{array}$ & $\begin{array}{l}\text { a. soil A } \\
( \pm N \text { and } \\
\text { P) }\end{array}$ & petri dish & 7 & 1 & 3 & 100 & $22^{\circ} \mathrm{C}$ & germ. $\%$ \\
\hline & increments) & $\begin{array}{l}0.4,1,1.5 \\
2,3,4,5,6\end{array}$ & $\begin{array}{l}\text { b. soil B } \\
( \pm N \text { and } \\
\text { P) }\end{array}$ & petri dish & 7 & 1 & 3 & 100 & $22^{\circ} \mathrm{C}$ & as above \\
\hline & & & c. soil A & petri dish & 14 & 1 & 1 & 100 & $22^{\circ} \mathrm{C}$ & as above \\
\hline \multirow[t]{3}{*}{$\begin{array}{l}\text { Smith et } \\
\text { al.2006 }\end{array}$} & $\begin{array}{l}\text { a. } 7 \text { PAHs mix } \\
\text { (F) }\end{array}$ & 0.1 & sandy soil & pots & 14 & 7 & 4 & $\begin{array}{l}0.2 \mathrm{~g} \\
(\mathrm{each}\end{array}$ & $40 / 10^{\circ} \mathrm{C}$ & germ. $\%$, at day 84 - foliage dry weight \\
\hline & b. coal tar $(\mathrm{F})$ & 0.16 & sandy soil & pots & 14 & 7 & 4 & species) & & as above \\
\hline & $\begin{array}{l}\text { c. coking plant } \\
\text { soil (A) }\end{array}$ & 0.5 & $\begin{array}{l}\text { sandy clay } \\
\text { loam }\end{array}$ & pots & 14 & 7 & 4 & & & as above \\
\hline $\begin{array}{l}\text { Smreczak } \\
\text { and } \\
\text { Kordybach } \\
2003\end{array}$ & $\begin{array}{l}\text { PAHs mix } \\
\text { (fluorene, } \\
\text { pyrene, } \\
\text { anthracene, } \\
\text { chrysene) }\end{array}$ & $\begin{array}{l}1,10,100 \\
\left(\mathrm{mg} \mathrm{kg}^{-1}\right)\end{array}$ & $\begin{array}{l}\text { a. light } \\
\text { loamy soil } \\
\text { b. light } \\
\text { loamy soil } \\
+ \text { compost }\end{array}$ & $\begin{array}{l}\text { glass petri } \\
\text { dish }\end{array}$ & 7 & 4 & 4 & $8-10$ & $20^{\circ} \mathrm{C}$ dark & germ. $\%$, root length \\
\hline $\begin{array}{l}\text { Udo and } \\
\text { Fayemi } \\
1975\end{array}$ & crude oil $(\mathrm{F})$ & $\begin{array}{l}1.1,2.1, \\
4.2,6.4, \\
8.5,10.6\end{array}$ & soil & plastic pot & 7 & 1 & 3 & 4 & - & germ. $\%$, total biomass, nutrient uptake \\
\hline
\end{tabular}

